\title{
Climate variability and long-term expansion of peatlands in Arctic Norway during the late Pliocene (ODP Site 642, Norwegian Sea)
}

\author{
Sina Panitz ${ }^{1}$, Ulrich Salzmann ${ }^{1}$, Bjørg Risebrobakken ${ }^{2}$, Stijn De Schepper ${ }^{2}$, and Matthew J. Pound ${ }^{1}$ \\ ${ }^{1}$ Department of Geography, Faculty of Engineering and Environment, Northumbria University, Newcastle upon Tyne NE1 \\ 8ST, UK \\ ${ }^{2}$ Uni Research Climate, Bjerknes Centre for Climate Research, Allégaten 55, 5007 Bergen, Norway \\ Correspondence to: Sina Panitz (sina.panitz@northumbria.ac.uk)
}

Received: 25 November 2015 - Published in Clim. Past Discuss.: 21 December 2015

Accepted: 30 March 2016 - Published: 21 April 2016

\begin{abstract}
Little is known about the terrestrial response of high-latitude Scandinavian vegetation to the warmerthan-present climate of the late Pliocene (Piacenzian, 3.602.58 Ma). In order to assess Piacenzian terrestrial climate variability, we present the first high-resolution reconstruction of vegetation and climate change in northern Norway between 3.6 and 3.14 Ma. The reconstructions are derived from pollen assemblages in the marine sediments of ODP Hole $642 \mathrm{~B}$, Norwegian Sea $\left(67^{\circ} \mathrm{N}\right)$. The palynological assemblages provide a unique record of latitudinal and altitudinal shifting of the forest boundaries, with vegetation alternating between cool temperate forest during warmerthan-present intervals and boreal forest similar to today during cooler intervals. The northern boundary of the nemoral to boreonemoral forest zone was displaced at least $4-8^{\circ}$ further north, and warmest-month temperatures were 6$14.5^{\circ} \mathrm{C}$ higher than at present during warm phases. Warm climatic conditions persisted during the earliest Piacenzian (ca. 3.6-3.47 Ma) with diverse cool temperate nemoral to boreonemoral forests growing in the lowlands of the Scandinavian mountains. A distinct cooling event at ca. $3.47 \mathrm{Ma}$ resulted in a southward shift of vegetation zones, leading to the predominance of boreal forest and the development of open, low alpine environments. The cooling culminated around 3.3 Ma, coinciding with Marine Isotope Stage (MIS) M2. Warmer climate conditions returned after ca. 3.29 Ma, with higher climate variability indicated by the repeated expansion of forests and peatlands during warmer and cooler periods, respectively. Climate progres-
\end{abstract}

sively cooled after $3.18 \mathrm{Ma}$, resembling climatic conditions during MIS M2. A high variability of Norwegian vegetation and climate changes during the Piacenzian is superimposed on a long-term cooling trend. This cooling was accompanied by an expansion of Sphagnum peatlands that potentially contributed to the decline in atmospheric $\mathrm{CO}_{2}$ concentrations at the end of the Piacenzian warm period and facilitated ice growth through positive vegetation-snow albedo feedbacks. Correlations with other Northern Hemisphere vegetation records suggest hemisphere-wide effects of climate cooling.

\section{Introduction}

Preceding the glacial-interglacial cycles of the Pleistocene, the late Pliocene (Piacenzian Stage, 3.60-2.58 Ma; Gibbard et al., 2010) marks the last time interval in the Earth's history that was characterised by a sustained warmer-than-present climate (Lisiecki and Raymo, 2005). The mid-Piacenzian warm period (mPWP, 3.264-3.025 Ma) has been the subject of intensive palaeoclimate research due to its similarity to projections of future global warming and its nearmodern palaeogeography, palaeoceanography and palaeobiology (Dowsett, 2007; Dowsett et al., 2010; Haywood et al., 2013a; IPCC, 2013; Salzmann et al., 2009). During the $\mathrm{mPWP}$, average global mean annual surface temperatures were about $2-3^{\circ} \mathrm{C}$ higher than at present (Haywood et al., 2013b). As the duration of the mPWP exceeds orbital timescales, its warmth was not driven by insolation changes 
but rather by differences in the state of boundary conditions intrinsic to the climate system itself (Haywood et al., 2013a; Miller et al., 2010; Pound et al., 2014). Relatively high atmospheric $\mathrm{CO}_{2}$ concentrations with values of about 270 $400 \mathrm{ppm}$ have been identified as the most important cause of Piacenzian warmth, while differences in orography, vegetation and ice sheets constitute the remaining proportion of warming relative to the modern period (Badger et al., 2013; Lunt et al., 2012; Martínez-Botí et al., 2015; Pagani et al., 2010; Seki et al., 2010).

In the North Atlantic and Nordic Seas both marine and terrestrial records reveal a strong warming at high latitudes during the Piacenzian. Sea surface temperatures (SSTs) were up to $8^{\circ} \mathrm{C}$ warmer than at present in the Nordic Seas as opposed to only $\sim 2-4{ }^{\circ} \mathrm{C}$ in the midlatitudes (Dowsett et al., 2013). The amplified warming has been suggested to be related to an enhanced Atlantic Meridional Overturning Circulation (AMOC) (see, e.g., Dowsett et al., 2013; Robinson, 2009). However, model simulations indicate a similarto-present AMOC during the mPWP, supporting the notion that the amplified warming in the Nordic Seas was a result of increased radiative forcing (Zhang et al., 2013). On land, boreal taiga forests reached the coast of the Arctic Ocean during the Piacenzian and tundra biomes were markedly reduced (Bennike et al., 2002; Rybczynski et al., 2013; Salzmann et al., 2008; Willard, 1996). In the high Artic, Pliocene deposits reveal mean annual temperatures (MATs) $\sim 19^{\circ} \mathrm{C}$ warmer than at present, favouring the growth of larch-dominated forests on Ellesmere Island (Ballantyne et al., 2006, 2010; Rybczynski et al., 2013). In contrast, vegetation changes were less profound in the midlatitudes. The prevalence of mixed forests in eastern Arctic Canada during the Piacenzian suggests a northward shift of the northern boundary of the deciduous forest zone by a minimum of $5^{\circ}$ latitude with MATs $3-5^{\circ} \mathrm{C}$ warmer than at present (de Vernal and Mudie, 1989a; Willard, 1994). In Norway, warm-temperate taxa occur at least $7^{\circ}$ further north of their present limit, pointing towards substantially warmer conditions (Willard, 1994). A northward latitudinal shift of vegetation of about $10^{\circ}$ is inferred from the presence of mixed to boreal forest on Svalbard during the Pliocene (Willard, 1996).

The mPWP has often been described as a relatively stable warm period with only minor temporal variations in climate and vegetation distribution (see, e.g., Willard, 1994; Thompson and Fleming, 1996). Up to the present, high-resolution vegetation records with a robust age control are missing for the surroundings of the North Atlantic and Nordic Seas, and it is unclear whether the available palaeoclimate records represent the full variability or peak warm phases of the Piacenzian only. A recently published high-resolution pollen record from Lake El'gygytgyn in the north-eastern Russian Arctic reveals major changes in the dominant biome distribution during the Piacenzian, ranging from temperate cool mixed forests to Arctic shrub tundra vegetation (Andreev et al., 2014).
Data-model comparison studies suggest that climate models currently underestimate the magnitude of mPWP warming that is evident in proxy-based SST reconstructions for the Nordic Seas (Dowsett et al., 2013). The data-model discrepancy has been partly ascribed to the comparison of simulations that represent a discrete time interval to timeaveraged proxy data (Dowsett et al., 2013; Salzmann et al., 2013). A recent modelling study indicates that the Norwegian Current, which strongly affects the climate of Norway, may have been cooler than at present when altered palaeogeographic boundary conditions are considered (Hill, 2015). In order to resolve these uncertainties a time slice centred around 3.205 Ma (Marine Isotope Stage (MIS) KM5c) has been proposed for future palaeoclimate research in the Piacenzian, requiring high-resolution proxy records (Haywood et al., 2013a).

Here we present a new high-resolution reconstruction of Piacenzian vegetation and climate changes for Arctic Norway based on the recently redated Ocean Drilling Program (ODP) sediment core 642B (Risebrobakken et al., 2016). The aim of this study is (1) to assess the evolution and temporal variability of vegetation and climate changes in Norway during the Piacenzian, (2) to determine their magnitude, and (3) to evaluate the potential of glacier and ice sheet build-up on Scandinavia during cold intervals of the Piacenzian.

\section{Geographical setting}

\subsection{Oceanographic location of ODP Hole 642B}

ODP Hole 642B is located on the outer Vøring Plateau in the Norwegian Sea about $400-450 \mathrm{~km}$ west of Norway $\left(67^{\circ} 13.2^{\prime} \mathrm{N}, 2^{\circ} 55.8^{\prime} \mathrm{E} ; 1286 \mathrm{~m}\right.$ water depth; Shipboard Scientific Party (1987); Fig. 1). On either side of the Vøring Plateau a branch of the Norwegian Atlantic Current (NwAC) flows northward. The eastern branch follows the continental slope of Norway and the western branch flows around the Vøring Plateau. Atlantic Water is spread between both branches and lies above the site (Nilsen and Nilsen, 2007). The branches of the NwAC are an extension of the North Atlantic Current (NAC) which in turn is a continuation of the Gulf Stream (Orvik, 2002). The eastern branch of the NwAC enters the Nordic Seas (Greenland Sea, Iceland Sea and Norwegian Sea) across the Iceland-Faroe Ridge, while the Western branch flows through the Faroe-Shetland Channel (Hansen and Østerhus, 2000).

\subsection{Present-day climate and vegetation of Norway}

As a result of the influence of the NAC and warm westerly and south-westerly winds, the climate of Norway is maritime with mild winters and higher MATs than any other area at comparable latitudes (Diekmann, 1994). Due to its geographic location and the Scandinavian mountains that run from north to south, the climate and vegetation of Nor- 


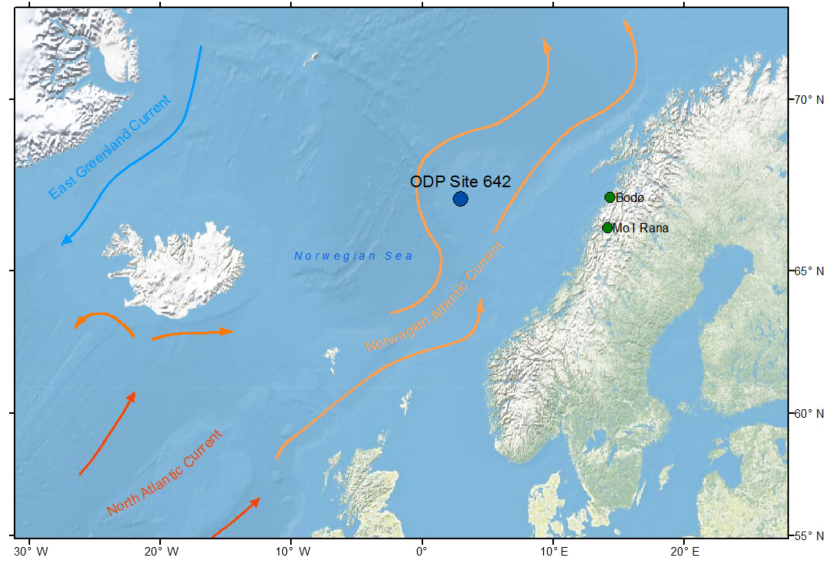

Figure 1. Location of ODP Site 642 in the Norwegian Sea. Meteorological stations used for present-day climate data are located in Bod $\varnothing$ and Mo i Rana in northern Norway. Colour coding indicates the relative temperature of currents: red - warm; orange - moderately warm; blue - cold.

way changes along three gradients: latitudinal, altitudinal and continental (Moen, 1987). While MATs decrease with increasing latitude as well as altitude and continentality, precipitation decreases from west to east, being highest along the south-west coast of Norway (Diekmann, 1994).

In northern Norway (Nordland) mean annual temperatures (MATs) and warmest-month temperatures (WMTs, July) range, respectively, between -6 and -4 and $4-8{ }^{\circ} \mathrm{C}$ at the higher altitudes and $4-6$ and $12-16^{\circ} \mathrm{C}$ along the coast (Moen, 1999). Bod $\varnothing\left(67^{\circ} \mathrm{N}\right)$ and Mo i Rana $\left(66^{\circ} \mathrm{N}\right)$ are the closest meteorological stations to ODP Hole 642B (Fig. 1), from which climate data is available for the last 30 years from the Meteorological Institute of Norway. Present-day MATs average $-0.5^{\circ} \mathrm{C}$, with values ranging between $\sim-2.5$ and 1.7 , and warmest-month temperatures reach $9.8^{\circ} \mathrm{C}$ on average, ranging between 5.8 and $13.8^{\circ} \mathrm{C}$ (Norwegian Meteorological Institute and Norwegian Broadcasting Corporation, 2014). In Norway precipitation follows a strong eastwest gradient. Mean annual precipitation (MAP) ranges from 1000 to $2500 \mathrm{~mm}$ along a broad south-north-stretching coastal belt and only drops below $1000 \mathrm{~mm}$ further inland. In the area around Bod $\varnothing$ and Mo i Rana, MAP is 10001500 mm (Diekmann, 1994; Moen, 1999).

Most of Norway is covered by boreal and alpine vegetation today (Fig. 2). In the south, the boreal zone transitions into the temperate deciduous forests of central Europe. In the north $\left(\sim 70^{\circ} \mathrm{N}\right)$ and at higher elevations, the boreal zone is limited by the tree line formed by the birch tree Betula pubescens and borders the Arctic and alpine tundra (Moen, 1987, 1999). The altitudinal limit of the tree line above which alpine tundra dominates decreases gradually from $\sim 1200 \mathrm{~m}$ above sea level (a.s.l.) in the southern Scandinavian mountains to sea level in northernmost Norway (Moen, 1999). The flora becomes less diverse and for-

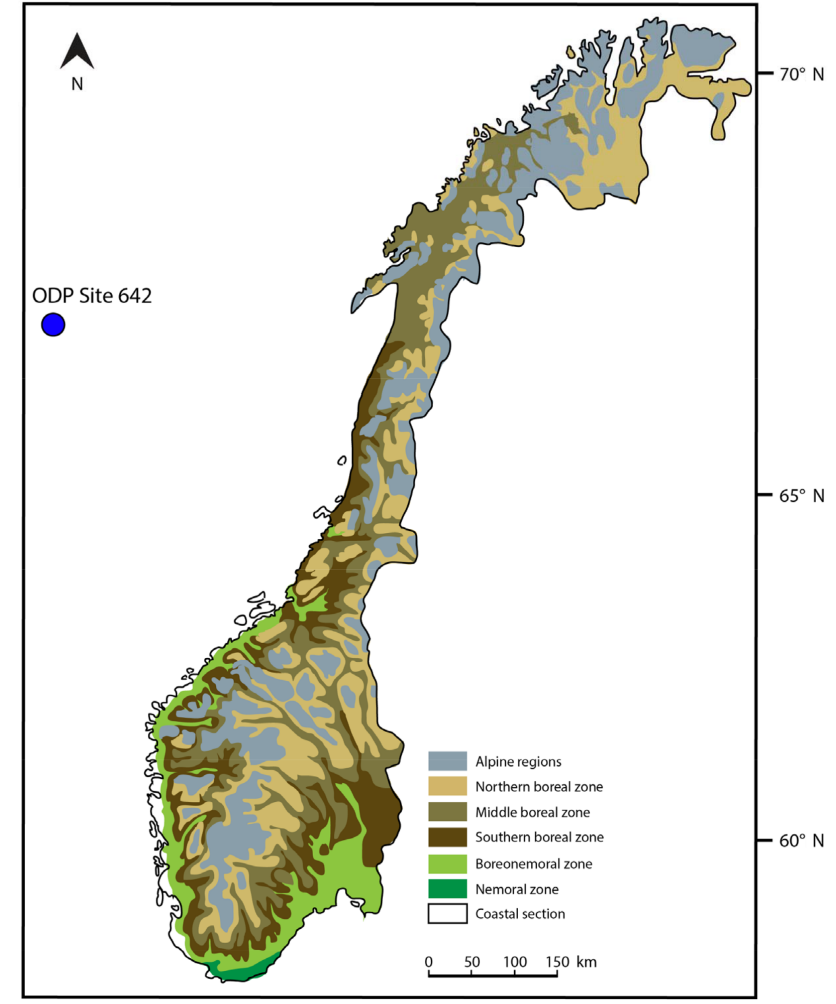

Figure 2. Vegetation map of Norway modified after Moen (1987). Position of ODP Site 642 was drawn according to scale.

est productivity as well as tree density decline from south to north (Moen, 1987). Temperate deciduous forest is only found along the far south coast and is characterised by the absence of Picea abies (Fig. 2) (Diekmann, 1994; Moen, 1987).

The boreal zone is divided into four subzones (boreonemoral and southern, middle and northern boreal zone; Fig. 2), which follow climatic gradients. The climate of the boreal zone is characterised by cold winters, long-lasting snow cover and a short growing season (Moen, 1987). The southernmost boreal zone (boreonemoral) mainly consists of Pinus sylvestris and Picea abies, with deciduous trees (e.g. Acer platanoides, Fraxinus excelsior, Quercus spp., Tilia cordata and Ulmus glabra) abundant under favourable local climatic conditions, especially on south-facing slopes (Diekmann, 1994). Presently, the boreonemoral zone extends over a continuous area in southern Norway but also occurs sporadically up to $\sim 64^{\circ} \mathrm{N}$ (Moen, 1987). The northern boreonemoral limit is defined by the northernmost distribution of Quercus forest, but the absence of oak forest in central Norway may also be due to geographical barriers (Diekmann, 1994; Moen, 1987).

In the southern boreal zone, deciduous forest is still present and wide areas are covered by raised bogs. The latitudinal boundary between the southern and middle boreal zone, dominated by coniferous forests, is located at $\sim 67^{\circ} \mathrm{N}$ (Fig. 2). Raised bogs reach their upper altitudinal limit in this 
zone (Moen, 1987). Along the coast the middle boreal zone extends to about $70^{\circ} \mathrm{N}$ where it transitions into the northern boreal zone, consisting of sparsely growing coniferous forest, a broad belt of birch forest (especially at higher altitudes in southern to central Norway) and peatlands (Moen, 1987). Beyond the northern boreal zone, alpine regions with grassheath communities extend at higher altitudes and latitudes (Moen, 1987).

Moen (1987) and Diekmann (1994) both separate a coastal section along the west and south-west coast of Norway that is distinct in climate and vegetation. Climatically, the coastal area is associated with mild winters, relatively cool summers and frequent precipitation. The modern vegetation, however, has been significantly altered by human activity, with the present dominance of open heathland (Calluna vulgaris) ascribable to logging and continuous burning and grazing cycles (Moen, 1987). Altantic raised bogs that naturally lack any marginal forest stretch along the coast, and the remaining forest stands are composed of Alnus spp., Betula spp., Corylus avellana, Fraxinus excelsior, Pinus sylvestris and Quercus spp. (Diekmann, 1994; Moen, 1987).

\subsection{Orography}

At present, mountains reach a maximum elevation of $1500 \mathrm{~m}$ in the areas surrounding Bod $\varnothing$ and Mo i Rana, with the tree line being lowest near the coast (400-500 m a.s.l.) and reaching elevations of up to $800 \mathrm{~m}$ a.s.l. further inland (Moen, 1999). During the Piazencian the Scandinavian mountains had already been uplifted; they were, however, lower than at present (Anell et al., 2009; Knies et al., 2014). Anell et al. (2009) report uplift of $\sim 1 \mathrm{~km}$ in northern Norway and 1$1.5 \mathrm{~km}$ in the southern Scandinavian mountains during the Neogene. These estimates correspond to the height of the Scandinavian mountains of 500 to $1000 \mathrm{~m}$ that was used for the Pliocene Research, Interpretation and Synoptic Mapping (PRISM3) reconstruction of Pliocene climate (Sohl et al., 2009), reducing them by $500-1000 \mathrm{~m}$ in altitude compared to the present.

\section{Materials and methods}

\subsection{Sample preparation and pollen analysis}

A total of 70 samples were taken from ODP Hole 642B, of which 68 samples were situated between 69.90 and $66.95 \mathrm{~m}$ below sea floor (m b.s.f.) (Shipboard Scientific Party, 1987). Additionally two surface samples were taken from the same core at 0 and $3 \mathrm{~cm}$ below sea floor in order to compare the Piacenzian to modern pollen assemblages. All samples were pre-sieved through a $63 \mu \mathrm{m}$ mesh in Bergen, Norway, to retain foraminifera for oxygen isotope analysis (Risebrobakken et al., 2016). In order to identify a potential bias in the pollen data resulting from the loss of larger Pinaceae pollen grains exceeding $63 \mu \mathrm{m}$, we compared sieved and un- sieved samples, and no difference in the overall pollen count was found. Samples were prepared for palynological analysis at the Palynological Laboratory Services Ltd, North Wales, and Northumbria University, Newcastle, using standard palynological techniques (Faegri and Iversen, 1989). One $L y$ copodium clavatum spore tablet was added to each sample to allow pollen concentration calculations to be made (Stockmarr, 1971). The samples were treated with $\mathrm{HCl}(20 \%)$ and concentrated hydrofluoric acid (HF) (48\%) to remove carbonates and silicates, respectively. An additional wash with hot $\left(\mathrm{ca} .80^{\circ} \mathrm{C}\right) \mathrm{HCl}(20 \%)$ was necessary to remove fluorosilicates. The sediment was back-sieved through a $10 \mu \mathrm{m}$ screen and the residue was mounted on glass slides with glycerol-gelatine jelly.

The microscopic analysis was carried out using a Leica Microscope (DM 2000 LED) at magnifications of $400 \times$ and $1000 \times$. Pollen preservation is generally very good. An average of 510 pollen grains was counted per slide, or 185 grains excluding Pinus. On average 23 taxa were identified per sample. Only 10 samples yielded counts below 300 grains. Pollen identification was aided by the pollen reference collection at Northumbria University and the following literature: Erdtman et al. (1961), Moe (1974), Faegri and Iversen (1989), Beug (2004) and Demske et al. (2013). In situ Lycopodium clavatum spores were differentiated from the reference spores by distinct differences in shape and colour. The group Juniperus type only contains pollen grains that are split open, whereas Cupressaceae contains those that are still closed or have a papilla (Demske et al., 2013). Reworked pollen and spores were identified based on the thermal maturity of the exine as seen by their dark orange to brown colours and/or their presence outside their stratigraphic range. In addition to a discolouration to yellow/orange colours, particularly reworked bisaccates showed a high degree of compression, a faint alveolar structure of airsacks and mineral imprints (de Vernal and Mudie, 1989a, b; Willard, 1996). Cenozoic uplift phases and shifting depocentres as documented in Eidvin et al. (2014) are restricted to the basins off the Norwegian coast and should not have affected the coring site which is located on the Outer Vøring Plateau.

Pollen diagrams were generated with the software Tilia which was also used to perform stratigraphically constrained cluster analysis in order to delimit pollen zones (Grimm, 1987, 1990). The presented cluster analysis does not include Pinus to highlight the assemblage changes in the other pollen and spores. Pollen percentages were calculated on the total pollen sum excluding Pinus pollen, unidentified and reworked pollen and spores. Percentages of Pinus pollen was calculated based on the total pollen sum including Pinus. Rarefaction was applied to estimate the number of taxa at a constant count of grains (Birks and Line, 1992). Diversity was assessed using the Shannon index which takes into account the relative abundance of a taxon as well as the number of taxa. The Shannon index is zero if the assemblage is dominated by a single taxon and shows high values for as- 


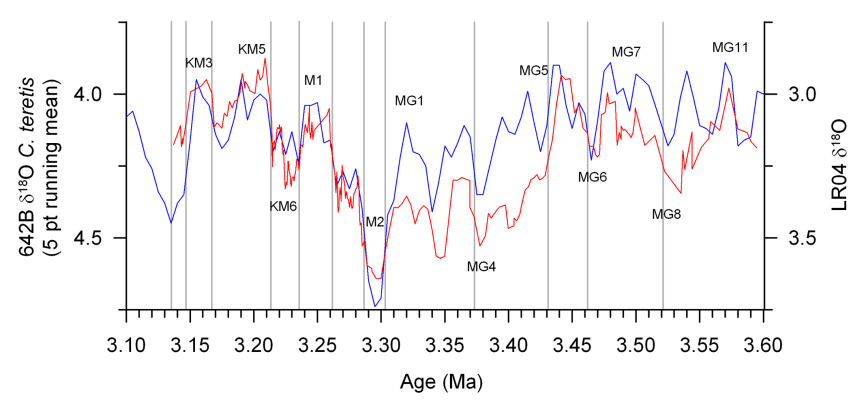

Figure 3. For the investigated time interval the age model of ODP Hole $642 \mathrm{~B}$ is based on correlating the 5-point smoothed benthic $\delta^{18} \mathrm{O}$ from 642B (Risebrobakken et al., 2016) with the global benthic oxygen isotope stack, LR04 (Lisiecki and Raymo, 2005). The LR04 stack is shown in blue and the smoothed 642B Cassidulina teretis $\delta^{18} \mathrm{O}$ record is shown in red. The grey vertical lines indicate the tie points defined by the correlation and were used when calculating the ages of Hole 642B. Indicated isotope stages refer to isotope stages as defined by Lisiecki and Raymo (2005).

semblages with many taxa that are each represented by few individuals (Hammer et al., 2001). Both rarefaction and diversity were calculated in PAST (PAleontologial STatistics, Hammer et al., 2001).

\subsection{Age model}

The Pliocene age model for ODP Hole 642B is based on the magnetic stratigraphy of Bleil (1989) updated to the Astronomically Tuned Neogene Time Scale (ATNTS) 2012 (Hilgen et al., 2012) and further correlation of the benthic oxygen isotopes to the global LR04 benthic $\delta^{18} \mathrm{O}$ stack (Fig. 3) (Lisiecki and Raymo, 2005; Risebrobakken et al., 2016). Across glacial MIS M2, the benthic $\delta^{18} \mathrm{O}$ signal is not any heavier than during other times of the Pliocene. This points to the possibility of a hiatus for the globally coldest part of MIS M2, even though a restricted local response to M2 cannot be excluded (Risebrobakken et al., 2016). A major hiatus exists after 3.14 Ma (Jansen and Sjøholm, 1991).

The investigated samples have an age range of 3.60 to 3.14 Ma. The upper part of the sequence, which coincides with the PRISM interval, has been counted at a high resolution (800 to 14700 years) and covers the central part of interglacial MIS KM5c (3.205 Ma). The earlier part of the Piacenzian was analysed at a lower resolution (6600 to 23300 years) in order to document the main climatic states and trends.

The modern sample presumably covers less than 2000 years, while the subsurface sample at $3 \mathrm{~cm}$ depth possibly reveals a maximum age of 6000 years. These assumptions are based on a modern sedimentation rate of $<2 \mathrm{~cm} \mathrm{kyr}^{-1}$ (Romero-Wetzel, 1989).

\subsection{Climate reconstruction}

To obtain quantitative estimates of Piacenzian climate, the coexistence approach (CA) of Mosbrugger and Utescher (1997) was applied. This approach uses the modern climatic tolerances of the nearest living relatives (NLRs) of the fossil taxa present in an assemblage to determine the climatic range in which these taxa could coexist. Climatic ranges have been quantified based on the presence or absence of all taxa for MAT and WMT, using the Palaeoflora database (Utescher and Mosbrugger, 2013).

To ensure accurate and reliable palaeoclimate estimates only samples with a minimum of 10 NLR taxa were used to determine the palaeoclimatic range. This led to the exclusion of two samples with a total count of less than 100 pollen grains. For this study a total of 38 taxa are used for the CA. All estimates are based on an average of 17 taxa per sample.

\section{Results}

\subsection{Modern pollen assemblages}

The analysed modern and mid-Holocene samples show pollen concentrations of 238 and 294 grains $^{-1}$ sediment, respectively (Fig. 4). Percentages of Pinus pollen (45-52\%) and Sphagnum spores (14-32\%) are highest in the two samples. Pollen of other conifers (Picea, Juniperus type and Taxus) are represented by proportions of less than $4 \%$, but Cupressaceae pollen accounts for $\sim 10 \%$ of the assemblage in the subsurface sample. The relative abundance of $L y$ copodium spores and undifferentiated monolete spores is also relatively high, with $\sim 6-15$ and $\sim 9 \%$, respectively. Betula is the most common deciduous tree pollen. Alnus, Corylus, Ericaceae, Fraxinus, Ilex aquifolium and Myrica pollen occur in very low numbers. Compared to the subsurface sample, the surface sample reveals a higher diversity of herb pollen (Asteraceae, Brassicaceae, Cyperaceae and Fabaceae). The proportion of reworked pollen and spores is relatively high in both samples (21-32\%).

\subsection{Piacenzian pollen assemblages}

\subsubsection{Pollen Zone 1 (69.9-69.0 m b.s.f.; ca. 3.60-3.47 Ma; 13 samples)}

Pollen Zone (PZ) 1 is characterised by a high abundance of Pinus pollen (61-77\%) and pollen from other conifer trees (Picea, Cupressaceae, Juniperus type, Sciadopitys and Tsuga) (Figs. 5, 7). Juniperus type, Sciadopitys and Tsuga pollen reveals its maximum abundances of the entire pollen record with up to $\sim 22,18$ and $10 \%$, respectively, within this zone. Ericaceae pollen reaches a maximum of $\sim 16 \%$ in the middle of the zone and subsequently decreases to values of around 6\% towards the upper part. Alnus, Betula, Corylus, Quercus and Ulmus pollen is frequently present, whereas other deciduous tree pollen such as Carpinus and 


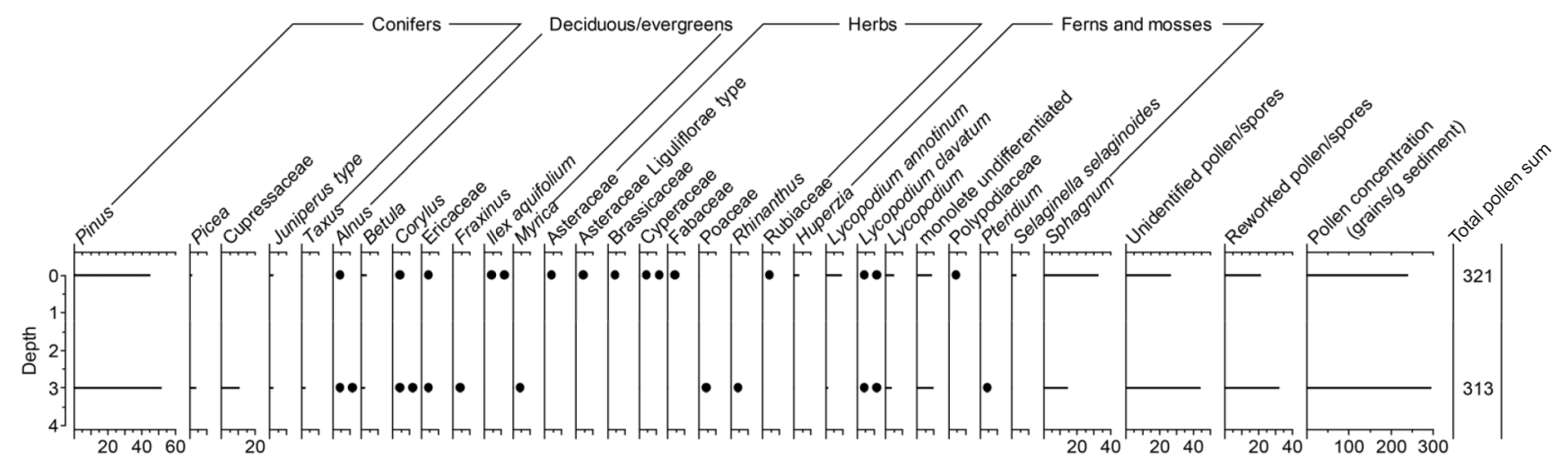

Figure 4. Pollen assemblages in the modern and mid-Holocene samples from ODP Hole 642B. Black circles are representative of single pollen or spore grains. Percentages of pollen and spores were calculated based on the pollen sum, excluding Pinus, unidentified and reworked pollen and spores.

Carya occurs only sporadically (Fig. 5). The abundance of herb pollen is generally low throughout PZ 1 . The number of Lycopodium (including L. annotinum, L. clavatum, $L$. inundatum and Lycopodium spp. indet.) spores is relatively high in the early part (up to $\sim 34 \%$ ), declining continuously throughout the interval. The relative abundance of Sphagnum spores is fairly constant, showing its lowest values $(<22 \%)$ within the entire study interval (Fig. 7). Spores of Huperzia, Osmunda, Polypodiaceae and undifferentiated monoletes are regularly found (Fig. 5). Rare pollen taxa only occur sporadically and the average diversity index across the zone is relatively low (Figs. 6, 7). The number of taxa increases towards the upper part of the interval (Fig. 7). Pollen concentrations mostly vary between $\sim 1000$ and 2000 grains $^{-1}$ sediment and peak at a maximum of 4300 grains $^{-1}$ sediment in the upper part of the zone. Reworked pollen and spores occur in low numbers with a maximum percentage of $\sim 4 \%$ (Fig. 5).

\subsubsection{Pollen Zone 2 (69-68.54 m b.s.f.; ca. 3.47-3.35 Ma; nine samples)}

The amount of Pinus remains high (65-75\%) throughout PZ 2, while percentages of Picea pollen decrease (Fig. 5). Pollen of other conifer trees (Cupressaceae, Juniperus type, Sciadopitys and Tsuga) shows a sharp decrease in numbers at the lower pollen zone boundary (Figs. 5, 7). Ericaceae pollen increases to maximum values of $\sim 18 \%$ in the upper part of the zone. The proportion of deciduous tree pollen is generally low. Betula pollen is consistently present, while the proportion of Alnus and Corylus pollen peaks in the middle of PZ 2. Pollen of Asteraceae, especially Asteraceae Liguliflorae type, shows maximum values of up to $31 \%$ in this zone, while other herb pollen remains low in abundance (Figs. 5, 7). Lycopodium spores peak in the lower and upper parts of PZ 2, reaching proportions of up to $56 \%$. A peak in the abundance of Sphagnum spores (43\%) is observed in the lower part of the zone (Fig. 7). Osmunda spores show high- est abundance and subsequently decrease until they disappear from the assemblage in the upper part. Huperzia spores become more abundant, and undifferentiated monolete spores are continuously present. Pteridium spores are also regularly found (Fig. 5). The number of rare pollen taxa is very low and the number of taxa and the diversity index show similar values to PZ 1 (Figs. 6, 7). Pollen concentrations reach maximum values of $\sim 2200$ grains $\mathrm{g}^{-1}$ sediment within the zone. Reworked pollen and spores first reach a relatively high proportion $(\sim 9 \%)$ in the middle part of this zone and peak again, after declining to values of $<3 \%$, in the upper part of the zone ( $\sim 15 \%)$ (Fig. 5).

\subsubsection{Pollen Zone 3a (68.54-68.365 m b.s.f.; ca. 3.35-3.29 Ma; five samples)}

The proportion of Pinus pollen is slightly reduced when compared to PZ 1 and 2 with percentages ranging between 43 and $66 \%$ (Fig. 5). Other conifer pollen remains low in abundance. Ericaceae pollen shows percentages of less than $10 \%$. Alnus, Betula and Corylus pollen is continuously present, whereas more temperate pollen taxa like Carpinus and Carya are absent. Asteraceae Liguliflorae-type pollen shows a pronounced peak $(\sim 10 \%)$ in the lower part of the zone, while other herb pollen taxa only occur sporadically and in low numbers (Fig. 5). Lycopodium spores reach their highest abundance in the lower part of the zone. A subsequent decline in the relative abundance of Lycopodium spores is accompanied by a distinct increase in Sphagnum spores, reaching proportions of up to $\sim 63 \%$ in the upper part of the zone (Fig. 7). The number of rare pollen taxa remains very low. The average diversity index is slightly higher when compared to PZ 1 and 2, whereas the number of taxa remains the same (Fig. 7). Pollen concentrations are relatively low with maximum values of $\sim 900$ grains $^{-1}$ sediment (Fig. 5). 


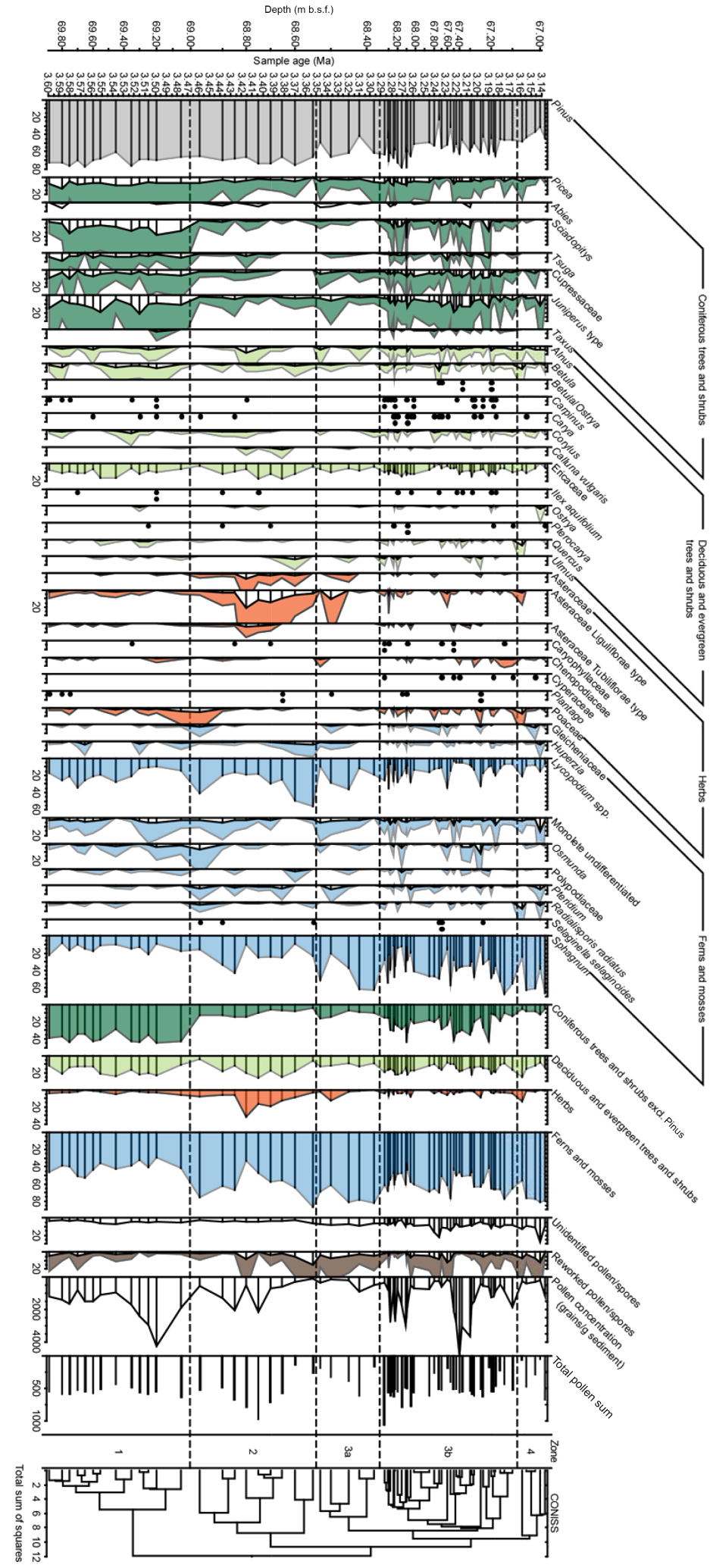

Figure 5. Pollen assemblages in the Piacenzian sediments of ODP Hole 642B. Non-patterned, coloured area represents 5-fold percentages. Black circles are representative of single pollen or spore grains. Percentages of pollen and spores were calculated based on the pollen sum, excluding Pinus, unidentified and reworked pollen and spores. Pinus was included in the pollen sum to calculate percentages of Pinus. The total pollen sum shown here comprises Pinus and unidentified pollen. Depth is indicated in metres below sea floor ( $\mathrm{m}$ b.s.f.). 


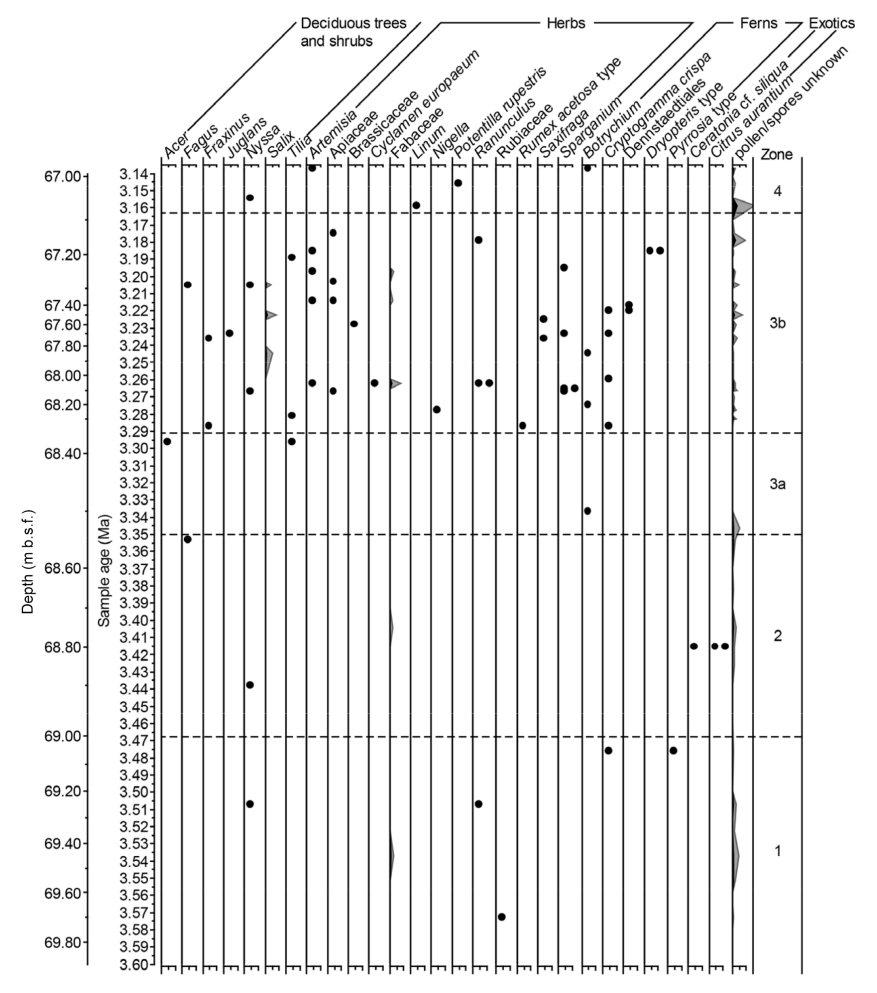

Figure 6. Pollen diagram showing taxa that occur in fewer than five samples. Grey areas represent five times the actual number. The exotic group marks taxa that have likely been transported to the site from the south. Depth is indicated in metres below sea floor (mb.s.f.).

\subsubsection{Pollen Zone 3b (68.365-67.09; ca. 3.29-3.16; 36 samples)}

PZ $3 \mathrm{~b}$ exhibits the highest sample density and shows a high variability, which is superimposed by a prevailing change in abundances (Figs. 5, 7). Pinus pollen shows relatively high values (43-79\%) in the lower part of the zone alongside an increased proportion of pollen from other conifer trees $(\mathrm{Cu}-$ pressaceae, Juniperus type, Picea, Sciadopitys and Tsuga). Subsequently the proportion of Pinus pollen stays around $50 \%$ before steadily increasing to a maximum of $\sim 65 \%$ in the upper part of the zone. Peaks in Pinus pollen are concurrent with higher abundances of the other conifer pollen (Figs. 5, 7). The relative abundance of Ericaceae pollen does not exceed $15 \%$. Alnus, Betula, Corylus and Quercus pollen occurs frequently in low percentages $(<9 \%)$. Other deciduous tree pollen, such as Carpinus, Carya, Ostrya, Pterocarya and Ulmus, as well as pollen of the evergreen shrub Ilex aquifolium are found regularly within PZ $3 \mathrm{~b}$ in low percentages. Asteraceae Liguliflorae-type pollen never exceeds $6 \%$ throughout the zone. Although still low in abundance, comparatively more taxa of herb pollen is present in this interval. Pollen of Artemisia as well as the families Apiaceae and Cyperaceae first appears in this pollen zone (Fig. 5). Lycopodium spores show a general decrease in abundance throughout the interval and alternate with high proportions of Sphagnum spores. After reaching a minimum of $11 \%$ the proportion of Sphagnum spores increases, reaching $\sim 68 \%$ in the upper part (Fig. 7). Spores of $\mathrm{Hu}$ perzia, Osmunda, Polypodiaceae, Pteridium and undifferentiated monolete spores occur frequently (Fig. 5). The number of rare pollen taxa is highest in this pollen zone (Fig. 6). The number of taxa counted on a constant pollen sum is highly variable (Fig. 7). In the lower part of the zone the diversity index shows a high variability, with the same average value as PZ 3a. Subsequently, the average diversity index of PZ $3 \mathrm{~b}$ increases markedly (Fig. 7). Pollen concentrations peak in the lower part (max. 300 grains $\mathrm{g}^{-1}$ sediment) and again

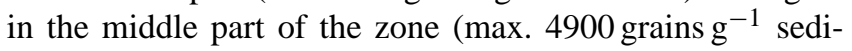
ment) (Fig. 5). The proportion of reworked pollen and spores is highest between 68.05 and $67.55 \mathrm{~m}$ b.s.f., reaching values of up to $\sim 13 \%$, and stays below $7 \%$ outside the interval (Fig. 5).

\subsubsection{Pollen Zone 4 (67.09-66.95 m b.s.f.; ca. 3.16-3.14 Ma; five samples)}

The amount of Pinus pollen varies between 32 and $48 \%$ and thus shows its lowest percentages within the entire Piacenzian record (Fig. 5). Pollen concentrations are also relatively low ( $<580$ grains $\mathrm{g}^{-1}$ sediment). While Picea and Ericaceae pollen decreases, Juniperus-type pollen percentages increase. Single pollen grains of Sciadopitys are still found, whereas pollen of Tsuga are absent. Alnus, Betula and Corylus pollen is consistently present, while pollen of other deciduous trees (Carya, Ostrya, Pterocarya and Quercus) only occurs sporadically. The diversity of herb pollen is reduced compared to PZ 3b (Fig. 5). Lycopodium spores are relatively low in abundance $(<21 \%)$, whereas the proportion of Sphagnum spores is high (up to $\sim 62 \%$ ) (Fig. 7). Huperzia and undifferentiated monolete spores peak in the upper part of the zone. Rare pollen taxa are present in relatively low numbers (Fig. 6). The number of taxa is comparable to $\mathrm{PZ2}$ and $3 \mathrm{a}$, and the average diversity index remains unchanged when compared to PZ $3 \mathrm{~b}$ (Fig. 7). Pollen concentrations are low with values $<1100$ grains $\mathrm{g}^{-1}$ sediment. Reworked pollen reaches proportions of up to $12 \%$ (Fig. 5).

\subsection{Quantitative palaeoclimate estimates}

Piacenzian temperature estimates using the CA show very wide ranges for each sample. MATs based on the CA range on average from 5 to $14{ }^{\circ} \mathrm{C}$, suggesting MATs $5-14{ }^{\circ} \mathrm{C}$ higher than at present in comparison to climate data from the reference stations. However, the lower end of the estimated MATs is similar to the modern coastal temperatures $\left(4-6{ }^{\circ} \mathrm{C}\right)$ (Moen, 1999). Piacenzian WMTs range on average from 18 to $24^{\circ} \mathrm{C}$ for most pollen assemblages, implying a rise in summer temperatures of $8-14^{\circ} \mathrm{C}$ when compared to climate data 


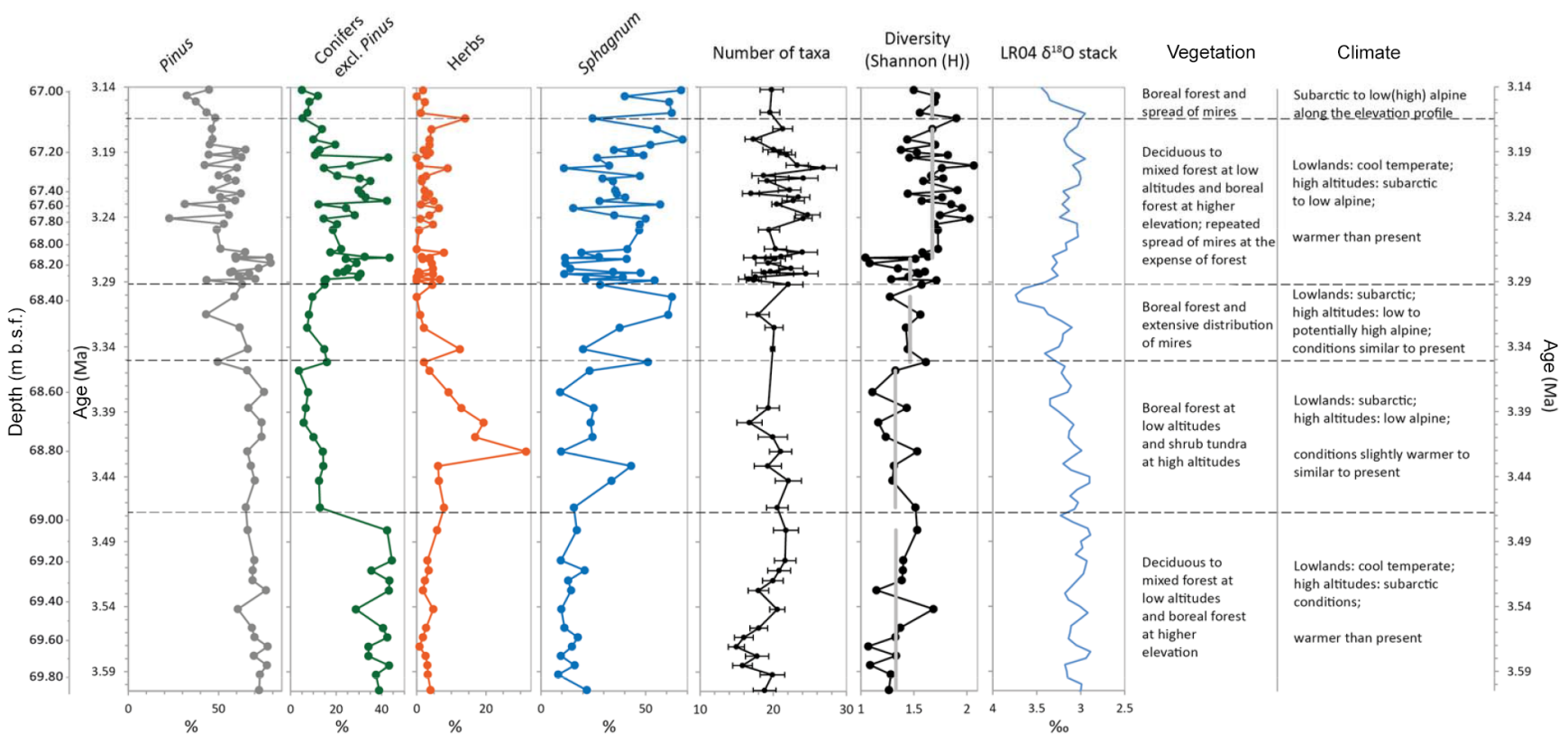

Figure 7. Summary diagram illustrating percentage changes in the main taxa or taxa groups, diversity based on the Shannon index, numbers of taxa rarefied at 300 individuals, the global benthic LR04 oxygen isotope stack (Lisiecki and Raymo, 2005) and description of the main vegetation configurations and climatic conditions. The vertical grey lines in the diversity graphs correspond to the average value across the interval. The dashed horizontal lines correspond to the main pollen zones shown in Fig. 5.

from the reference stations. In comparison to coastal values, these estimates are at least $2-8^{\circ} \mathrm{C}$ higher than at present (Moen, 1999). For the modern and mid-Holocene samples, WMTs match the upper end of the present-day coastal values of $12-16^{\circ} \mathrm{C}$ (Moen, 1999). However, MATs appear to be too warm and only match modern temperatures when the thermophilic taxa Ilex and Taxus, which occur in low numbers in modern and mid-Holocene samples, respectively (Fig. 4), are removed from the coexistence matrix.

\section{Discussion}

\subsection{Modern pollen assemblages and vegetation}

The modern and mid-Holocene samples from ODP Hole 642B were analysed in order to get a better understanding of the modern pollen signal in the marine sediments off Norway and to facilitate the interpretation of Piacenzian pollen assemblages. The pollen assemblages found in the two Holocene samples are representative of the modern vegetation of northern Norway, suggesting that northern Norway is the main source area for pollen and spores deposited at ODP Hole 642B. High abundances of Pinus pollen and Sphagnum spores reflect the extensive distribution of boreal forest and peatlands in northern Norway (Moen, 1987, 1999). Both fossil pollen grains are generally overrepresented in marine sediments. This effect becomes more pronounced with increasing distance from the shore due to their preferential transportation over long distances (see, e.g., Heusser, 1983;
Mudie and McCarthy, 2006). Nevertheless, percentages of Pinus pollen generally reflect its relative proportion in the vegetation community, and proportions of Sphagnum spores are highest where extensive peatlands are found onshore (see, e.g., Heusser, 1983; Mudie and McCarthy, 1994; Mudie, 1982). In contrast, pollen from deciduous trees is underrepresented in marine sediments as this pollen is deposited closer to the source area $(<200 \mathrm{~km})$, as a result of their small size and high density (Mudie and McCarthy, 2006). With ODP Hole $642 \mathrm{~B}$ being located $\sim 400 \mathrm{~km}$ offshore, the contrast between the relative abundance of Pinus and deciduous tree pollen is especially pronounced. The pollen spectra at ODP Hole 642B are dominated by wind-pollinated taxa, suggesting that wind is the main transport medium. There is no evidence for large rivers in Norway during the Pliocene, which makes rivers as a significant transport medium for pollen to the site highly unlikely. Today, plumes of cold fjord water enter the Norwegian Sea in spring but only extend less than $100 \mathrm{~km}$ offshore (Mork, 1981). However, modern-like fjords and glaciers which trigger such plumes almost certainly did not exist during the Pliocene.

The increase in Sphagnum spores and the slight decline in Pinus pollen in the mid- to late Holocene sample have been interpreted to reflect the expansion of peatlands that is observed in the late Holocene vegetation records from northern Norway (Bjune et al., 2004). Deciduous trees such as $A l$ nus and Betula are common elements in terrestrial Holocene vegetation records (see, e.g., Bjune and Birks, 2008; Bjune, 
$2005)$ but are only represented in low numbers $(<3 \%)$ in the marine surface pollen assemblages, complicating the quantification of their representation in the vegetation. The same applies for Corylus, which is a thermophilic, oceanic climate species in Norway and reaches its upper limit in the middle boreal zone, thus extending up to $70^{\circ} \mathrm{N}$ (Bjune, 2005; Moen, 1987). Other thermophilic taxa such as Fraxinus, Ilex and Taxus that are restricted to southern Norway $\left(<62.5^{\circ} \mathrm{N}\right)$ (Moen, 1987, 1999) are represented with a relative abundance of up to $2 \%$ in the modern and mid-Holocene pollen samples of Hole 642B, suggesting pollen input from a large source area. Human activity has, however, significantly altered the natural vegetation of Norway (Moen, 1987, 1999), resulting in the occurrence of species outside their natural habitat, which could explain the presence of Fraxinus and Taxus in the modern sample.

\subsection{Vegetation and climate at $3.60-3.47 \mathrm{Ma}$}

At the onset of the Piacenzian the occurrence of pollen from deciduous temperate elements (e.g. Carpinus, Carya and Quercus) together with high abundances of pollen from conifer trees, including temperate taxa such as Sciadopitys and Tsuga, suggest the presence of cool temperate deciduous to mixed forest in northern Norway. At present, Quercus spp. are a distinctly southern species in Norway, occurring in the nemoral and boreonemoral zones (Fig. 2). During the earliest Piacenzian the northern boundary of the boreonemoral zone was presumably positioned at least $4^{\circ}$ further north when compared to today, reaching the Arctic Circle. Predominantly deciduous forest might even have prevailed in the lowlands of northern Norway, implying a northward shift of the northern limit of the nemoral zone by at least $8^{\circ}$ latitude.

Sciadopitys and Tsuga are considered to be part of the cool temperate montane vegetation. Both species went extinct in Europe during the glacial-interglacial cycles of the Pleistocene but can still be found in east Asia and North America (see, e.g., Svenning, 2003; Wen, 1999). Only one species of Sciadopitys still exists at present, growing in the warm to cool temperate montane zone of Japan. There, Sciadopitys forests are associated with steep rocky ridges or slopes, requiring relatively dry habitat conditions in a humid climate (Ishikawa and Watanabe, 1986). In Neogene deposits from central Europe and Denmark Sciadopitys is, however, known to be an element of peat-forming vegetation or conifer forests that grew in better drained or elevated areas, respectively, suggesting that its ecological requirements have changed (see, e.g., Figueiral et al., 1999; Schneider, 1995). In the Lake Baikal region, Tsuga-Picea forests are also ascribed to habitats at higher altitudes during the Piacenzian (Demske et al., 2002). Our assignment of Sciadopitys and Tsuga to montane conifer forests is supported by the correlation of the relative percentage changes in these taxa to those of other high-altitude taxa (Cupressaceae, Juniperus type,
Picea; Fig. 5) (see, e.g., Numata, 1974; Seppä and Birks, 2001).

Ericaceae shrubs, Lycopodium and Sphagnum mosses likely originated from both the understorey of the cool temperate to boreal forests and open environments. The relative abundance of Sphagnum spores during the earliest Piacenzian is lower than that in the surface sample but similar to the subsurface sample (Figs. 4, 5), which might be indicative of a less extensive distribution of peatlands.

Warmer-than-present climatic conditions between 3.55 and 3.48 Ma have also been recorded at Lake El'gygytgyn in the north-eastern Russian Arctic where Larix-Pseudotsuga forests predominated (Andreev et al., 2014; Brigham-Grette et al., 2013). In southern east Siberia mixed coniferous forests grew under a relatively warm climate in the Lake Baikal region during the early Piacenzian (Demske et al., 2002).

\subsection{Vegetation and climate at $3.47-3.35 \mathrm{Ma}$}

A marked cooling around $3.47 \mathrm{Ma}$ and a subsequent establishment of similar-to-present boreal conditions are inferred from a sharp drop in the relative abundance of conifer tree pollen (except Pinus pollen). A corresponding increase in the abundances of spores and pollen from herbs, shrubs and mosses (Asteraceae, Ericaceae, Lycopodium and Sphagnum; Fig. 5) indicates the development of open environments at high altitudes, possibly similar to the modern low alpine vegetation. At present the lower boundary of the low alpine zone, corresponding to the tree line, is reached at $400-800 \mathrm{~m}$ in the area around Bodø and Mo i Rana (Moen, 1999).

Maximum abundance of herb pollen, especially that of Asteraceae Liguliflorae type, is reached at $3.42 \mathrm{Ma}$, steadily declining towards $3.35 \mathrm{Ma}$ (Figs. 5, 7). They are indicative of drier conditions. At present, tall-herb meadows reach their distribution limit in the southern Arctic zone in northern Norway but are less common in the alpine regions (Moen, 1999). The high abundance of Asteraceae in ODP Hole 642B might reflect a vegetation community with no modern analogue. At present, alpine environments with abundant Asteraceae can only be found in the Southern Hemisphere. At Kosciuszko National Park, New South Wales, Australia, Asteraceae grows in alpine herb fields, grasslands, bogs and heath communities along with Ericaceae, Huperzia, Lycopodium and Sphagnum (Costin et al., 2000). Additionally, Asteraceae and Ericaceae pollen as well as Lycopodium and Sphagnum spores in the sediments of ODP Hole 642B may have originated from the field layer of forests covering the lower altitudes. These were more boreal in character during this time interval with Pinus as the dominant species, as indicated by low percentages of pollen from other conifers, including the temperate taxa Sciadopitys and Tsuga (Fig. 5). The diversity index shows the lowest average value across this interval of relative cool climatic conditions (Fig. 7). 
The development of open environments at high altitudes implies an altitudinal downward shift of vegetation belts as well as a southward displacement of vegetation zones. Taxa characteristic of the boreonemoral zone (e.g. Quercus, Sciadopitys) comprise low proportions in the pollen assemblage at ODP Hole 642B between ca. 3.47 and 3.35 Ma (Fig. 5), suggesting that patches of deciduous to mixed forests grew in the area. These patches presumably represent extensions of the northern boundary of the mixed forest zone. The prevalence of boreal forest together with patchy deciduous forest stands and low alpine environments at higher altitudes is indicative of climatic conditions similar to today. Assuming tree line elevations of 400-800 m, the northern Norwegian mountains were probably not high enough for mountain glaciers to establish between 3.47 and 3.35 Ma. Presently, glaciers only form in the high alpine zone, above $1000 \mathrm{~m}$ (Moen, 1987, 1999).

While the ODP Hole 642B pollen record indicates cold conditions similar to the present day (Figs. 5, 7), reoccurring warmer and cooler climate conditions are documented in the Lake El'gygytgyn and Lake Baikal region between 3.47 and 3.35 Ma (Andreev et al., 2014; Demske et al., 2002). As in ODP Hole 642B, the pollen percentages of thermophilic tree species (Abies, Picea and Tsuga) also decrease significantly between ca. 3.48 and 3.45 Ma. At the same time, increased percentages of Poaceae and Cyperaceae pollen as well as Sphagnum and other spores indicate the development of open habitats, suggesting cooler and reoccurring drier and wetter climatic conditions around Lake El'gygytgyn (Andreev et al., 2014). The peak in Sphagnum spores at ca. 3.43 Ma in ODP Site 642B coincides with an increase in Sphagnum spores in the Lake El'gygytgyn record, suggesting wetter climatic conditions both in northern Norway and the Siberian Arctic. A biome reconstruction for Lake El'gygytgyn suggests the first appearance of tundra during a cool interval, lasting from 3.39 to $3.31 \mathrm{Ma}$ (Andreev et al., 2014). A thinning of the forests and spread of Ericaceae shrubs and Lycopodiaceae is also recorded at Lake Baikal at $3.47 \mathrm{Ma}$, but warm conditions prevail until 3.5 Ma (Demske et al., 2002). Between 3.5 and $3.38 \mathrm{Ma}$, drier but still relatively warm climatic conditions are inferred from a change in moist (Abies, Picea and Tsuga) to dry (Juniperus type, Quercus, Larix-Pseudotsuga) forests (Demske et al., 2002). A strong cooling is observed in the Lake Baikal region at 3.39 Ma from a spread of boreal taxa and a maximum in Selaginella selaginoides (Demske et al., 2002).

The period of cooling in Scandinavia, north-eastern Russian Arctic and southern east Siberia corresponds to the time of deposition of till, and hence glaciation, in the James Bay lowland, Canada $\left(\sim 52^{\circ} \mathrm{N}\right)$, at ca. $3.5 \mathrm{Ma}(3.6-3.4 \mathrm{Ma})$ (Gao et al., 2012) and also to enriched global benthic $\delta^{18} \mathrm{O}$ (Lisiecki and Raymo, 2005). No major glacial events are, however, evident in the Nordic Seas during this time interval (Fronval and Jansen, 1996; Kleiven et al., 2002). Gao et al. (2012) propose that the lack of ice-rafted detritus in the
Nordic Seas either indicates a significant contribution from the North American ice sheet to the elevated benthic $\delta^{18} \mathrm{O}$ values or a restriction of glaciation to the continental interior of Greenland and Fennoscandia. The Piacenzian vegetation record for northern Norway suggests a wide distribution of boreal forest between 3.47 and $3.35 \mathrm{Ma}$. Considering the present-day average minimum elevation of glaciers $(\sim 1000 \mathrm{~m})$ in northern Norway and a lower height of the Scandinavian mountains during the Pliocene, mountainous glaciation seems highly unlikely (Andreassen et al., 2012; Sohl et al., 2009).

In the North Atlantic, SSTs derived from alkenones decrease at $3.45 \mathrm{Ma}$ at Integrated Ocean Drilling Program (IODP) Site U1313 $\left(41^{\circ} \mathrm{N}, 33^{\circ} \mathrm{W}\right)$ just north of the subtropical gyre, suggesting a weakened northward heat transport via the NAC (Naafs et al., 2010). At ODP Site $982\left(58^{\circ} \mathrm{N}\right.$, $16^{\circ} \mathrm{W}$ ), which sits at the northern end of the NAC, a gradual cooling of SSTs (alkenones) is recorded from ca. $3.5 \mathrm{Ma}$ onwards (Lawrence et al., 2009). These SST records confirm the hemispheric-wide extent of climatic changes around ca. 3.47 Ma.

\subsection{Vegetation and climate at 3.35-3.29 Ma}

After ca. 3.35 Ma the percentages of Pinus pollen drop below $50 \%$, suggesting a decline in pine forest coverage and a further cooling of climate (Fig. 5). Around 3.3 Ma the high relative abundance of Sphagnum spores reflects a spread of peatlands and high precipitation (Fig. 7). Additionally, the absence of temperate pollen taxa, e.g. Carpinus, Carya, Sciadopitys and Tsuga, is indicative of the predominance of boreal forest. The proportion of Sphagnum spores is about twice as high around $3.3 \mathrm{Ma}$ than in the surface sample, suggesting a more extensive distribution of peatlands.

The upper limit of well-developed peatland communities is presently reached in the lower alpine zone. The maximum elevation of this zone ranges from 600 to $1400 \mathrm{~m}$ where the Scandinavian mountains reach a sufficient height (Moen, 1987, 1999). The clear boreal to alpine character of the vegetation around 3.3 Ma suggests that climatic conditions might have been cold enough to allow for the establishment of mountain glaciers in northern Norway. The cooling event at ca. 3.3 Ma coincides with glacial MIS M2, a major global glaciation event. In the Northern Hemisphere a modern-like ice configuration with glaciation in Greenland, Iceland, the Barents Sea and Scandinavia is suggested for MIS M2 (De Schepper et al., 2014). However, the possibility of a hiatus in ODP Hole 642B over the most extreme part of MIS M2 must be considered (Fig. 3) (see Sect. 3.2).

At Lake El'gygytgyn a further increase in herbs and spores combined with a decrease in tree taxa is observed at $3.352 \mathrm{Ma}$, indicating enhanced cooling and relatively dry climatic conditions (Andreev et al., 2014). Between 3.310 and $3.283 \mathrm{Ma}$, tundra- and steppe-like vegetation dominated around the lake but tree and shrub vegetation was still present 
in the area. A high Sphagnum content also points to the existence of wetlands around the lake (Andreev et al., 2014). In the lake Baikal region, cool climatic conditions still persisted around 3.3 Ma (Demske et al., 2002).

\subsection{Vegetation and climate at 3.29-3.16 Ma}

After 3.29 Ma, cool temperate deciduous to mixed forests remigrated to northern Norway as shown by the frequent presence of pollen from temperate deciduous taxa (e.g. Carpinus, Carya, Pterocarya and Quercus) and the increase in the relative abundance of conifer pollen (Fig. 5). Between 3.29 and 3.26 Ma, pollen percentages of Pinus and conifers are high, while those of Sphagnum spores are relatively low, suggesting a spread of forest at the expense of peatlands and thus warmer climatic conditions. A reestablishment of Pinus-Larix-Picea forests after MIS M2 is also documented at Lake El'gygytgyn, and mixed coniferous forests spread in the Lake Baikal region (Andreev et al., 2014; Demske et al., 2002).

In the pollen record of ODP Hole 642B an opening of the vegetation is seen at ca. $3.26 \mathrm{Ma}$, when the relative abundance of Pinus pollen and Lycopodium spores decreases. The correspondingly increased proportion of Sphagnum spores suggests wetter and possibly also cooler climatic conditions (Fig. 5). Thereafter, percentages of Pinus are quite variable, suggesting repeated warmer phases. Taxa diversity is higher during the warmest climatic conditions within the Piacenzian record (3.29-3.18 Ma) when compared to the preceding cool intervals (3.47-3.29 Ma). This coincides with a higher number of taxa in individual samples (Fig. 7). In the north-eastern Russian Arctic an opening of the vegetation and drier climatic conditions is inferred from the high amounts of herb pollen in the Lake El'gygytgyn record between ca. 3.25 and 3.20 Ma (Andreev et al., 2014). This coincides with low Pinus pollen and high Sphagnum spore percentages in the sediments of ODP Hole 642B. Cooler climate conditions are also recorded in the Lake Baikal region during this interval (Demske et al., 2002). In northern Norway climate oscillated between cooler and warmer phases. The high abundance of Pinus pollen in the sediments of ODP Hole 642B around 3.20-3.18 Ma coincides with a re-establishment of forests around Lake El'gygytgyn at ca. 3.20 Ma (Andreev et al., 2014). The decline in the relative abundance of Pinus pollen and marked increase in the proportion of Sphagnum spores after 3.18 Ma suggest the establishment of cooler climatic conditions similar to those during MIS M2.

Over the entire 3.29-3.16 Ma interval, a wider distribution of cool temperate montane forests in northern Norway during warmer phases is indicated by peaks in the abundances of Sciadopitys and Tsuga pollen, coinciding with high Pinus pollen contents (Fig. 5). Thermophilic pollen taxa like Carpinus, Carya, Ilex, Pterocarya and Quercus occur frequently, together with other rarely represented pollen of deciduous trees (e.g. Acer, Fagus, Juglans, Nyssa and Tilia), pointing to the presence of nemoral to boreonemoral forests and a warm climate (Figs. 5, 6). Relatively high numbers of Juniperus type and Cupressaceae pollen suggest the prevalence of open shrub vegetation at higher altitudes throughout the interval (Bjune, 2005; Seppä and Birks, 2001). The high proportion of Sphagnum spores, peaks in herbs such as Asteraceae, Chenopodiaceae and Poaceae pollen, and the regular occurrence of other herb pollen taxa also suggest the continuous presence of open environments (Fig. 5). The relatively high abundance of Sphagnum spores also points to more humid conditions than during the previous intervals.

The negative correlation of Pinus and Sphagnum pollen percentages suggests distinct changes between a wider forest coverage and expansion of peatlands, presumably indicative of repeatedly warmer and cooler climatic conditions. The development of peatlands during Piacenzian intervals that show a similar-to-present vegetation distribution and climate might have contributed to the long-term decline in atmospheric $\mathrm{CO}_{2}$ concentrations towards the Pleistocene (see, e.g., Lunt et al., 2008; Martínez-Botí et al., 2015; Pound et al., 2015). At present circumarctic peatlands in the Northern Hemisphere form a major carbon sink (see, e.g., Gajewski et al., 2001; MacDonald et al., 2006). In addition, a change from a taiga- to tundra-dominated vegetation significantly increases surface albedo by expanding snow cover over the summer (Koenig et al., 2011, and references therein). The wider distribution in peatlands in northern Norway during the Piacenzian might have acted as a positive internal feedback mechanism that facilitated the development of an extensive Scandinavian ice sheet around 2.72 Ma (Kleiven et al., 2002).

Our findings corroborate a previous palynological analysis of nine samples from the Piacenzian section of ODP Hole $642 \mathrm{C}$, indicating the presence of a mixed conifer-hardwood forest at the northern limits of the deciduous forest zone in Norway between ca. 3.3 and 3.1 Ma (Willard, 1994). However, our high-resolution study indicates that the warmth of the Piacenzian was not as stable as previously thought but was instead interrupted by cooler intervals, causing latitudinal and altitudinal shifts of the boundary between the deciduous and boreal forest zone.

In the North Atlantic, a return of warm conditions at 3.29 Ma is documented in the alkenone-based SST record of Site U1313, indicating an enhanced northward heat transport by the NAC (Naafs et al., 2010). A re-establishment of the NAC at $3.285 \mathrm{Ma}$, following the glacial maximum of MIS M2, is also seen in the alkenone- and $\mathrm{Mg} / \mathrm{Ca}$-derived SSTs as well as dinoflagellate assemblage changes at IODP Site U1308 $\left(50^{\circ} \mathrm{N}, 24^{\circ} \mathrm{W}\right)$ and Deep Sea Drilling Project (DSDP) Site $610\left(53^{\circ} \mathrm{N}, 19^{\circ} \mathrm{W}\right)$ further north (De Schepper et al., 2013). The warming documented at these sites is in agreement with this study. In contrast, Site 982 records a continuous cooling over this interval which might, however, be attributed to discrepancies in the age model (Khélifi et al., 2012; Lawrence et al., 2009, 2013). 


\subsection{Vegetation and climate at 3.16-3.14 Ma}

The climate of Norway cooled further, as indicated by the steady decrease in the relative abundance of Pinus pollen, high proportions of Sphagnum spores and the sporadic occurrence of pollen from temperate taxa between ca. 3.16 and 3.14 Ma (Figs. 5, 7). The pollen assemblage shows a strong resemblance to that during MIS M2, suggesting similar or slightly colder climatic conditions when compared to today and potentially creating conditions favourable for glacier build-up at high altitudes. Cool climate prevailed in the James Bay lowland, Canada, during that time, as indicated by the prevalence of boreal forests (Gao et al., 2012). A thinning of forests and deflection to cooler conditions is also observed at Lake Baikal at ca. 3.18 and 3.15 Ma (Demske et al., 2002). In contrast, conifer forests grew under relatively warm climate conditions until $3.06 \mathrm{Ma}$ in the Lake El'gygytgyn area (Andreev et al., 2014).

\subsection{Late Pliocene climate reconstruction}

According to the pollen assemblages, the northern boundary of the boreonemoral and nemoral zone was shifted $4-8^{\circ}$ latitude to the north during the two warmer-than-present intervals in the Piacenzian (3.6-3.47 and 3.29-3.18 Ma). Conditions rather similar to the present characterised the interval between 3.47 and 3.29 Ma.

Palaeoclimate estimates for the Piacenzian using the coexistence approach suggest that MATs and WMTs were at least 4 and $8{ }^{\circ} \mathrm{C}$ higher than today, respectively. These minimum estimates fit well with the reconstructed latitudinal shifts in forest zones and broadly corroborate previous temperature estimates from this site (Willard, 1994). Despite this match, it should be noted that the CA is only of very limited use in our study. Factors which hamper accurate climate estimates include the following:

- Uncertainties in pollen identification allow a determination of many pollen taxa to genus level only. This yields wide climatic tolerances and ranges.

- The distance of the site from the mainland results in an overall lower number of taxa and complicates the identification of the pollen source area.

- Scandinavian mountains near the coast cause a mixed pollen signal, with taxa from different vegetation and climate zones along the altitudinal gradient.

- The lack of modern analogue is problematic as several taxa are extinct in Europe, such as Carya, Sciadopitys and Tsuga, and their modern distribution might not reflect their climatic tolerances during the Pliocene.

Considering these limitations, the Piacenzian climate reconstruction based on the CA for northern Norway should be considered a low-confidence estimate only.

\section{8 (Sub)Arctic vegetation evolution during the Piacenzian}

During the Cenozoic, temperate to boreal forests showed a wide distribution in the Northern Hemisphere and were very uniform in their floristic composition (see, e.g., Wen, 1999; Xing et al., 2015). Palaeogeographic and palaeoclimatic changes during the Pliocene and Pleistocene led to today's disjunct distribution of tree genera in Europe, Asia and North America (see, e.g., Svenning, 2003; Xing et al., 2015). The Piacenzian flora of northern Norway exhibits a similar composition to that in Canada and Siberia at that time (see, e.g., Andreev et al., 2014; Pound et al., 2015; de Vernal and Mudie, 1989a). The reconstructed Piacenzian vegetation and climate changes in northern Norway are closely correlated with other vegetation records across the Northern Hemisphere (Table 1), indicating a hemispheric response to external and internal forcing. Vegetation changes at Lake El'gygytgyn strongly follow orbitally induced glacialinterglacial cycles (Andreev et al., 2014; Brigham-Grette et al., 2013). For instance, the hemisphere-wide cooling at ca. 3.48-3.47 Ma and ca. 3.3 Ma coincides with MIS MG6 and M2, respectively (Andreev et al., 2014; Brigham-Grette et al., 2013; Lisiecki and Raymo, 2005).

The circumarctic distribution of tundra or peatlands developed during the late Piacenzian and throughout the glacialinterglacial cycles of the Pleistocene (see, e.g., Andreev et al., 2014; Gajewski et al., 2001). The transition of highlatitude vegetation changes from forest to tundra environments during the late Piacenzian presumably amplified the cooling through vegetation-snow albedo feedbacks (see, e.g., Gallimore and Kutzbach, 1996; Koenig et al., 2011). The long-term cooling trend over the Piacenzian that is observed in all records is in accordance with declining atmospheric $\mathrm{CO}_{2}$ values from the Piacenzian towards the early Pleistocene (Bartoli et al., 2011; Martínez-Botí et al., 2015; Seki et al., 2010). The expansion of tundra biomes may have contributed to the drawdown of atmospheric $\mathrm{CO}_{2}$, further enhancing cooling.

The main vegetation and climate changes during the Piacenzian observed in (sub)Arctic records are illustrated in Table 1. During the earliest Piacenzian diverse forest communities persisted under a warmer-than-present climate in northern Norway, the north-eastern Russian Arctic and southern east Siberia (Andreev et al., 2014; Demske et al., 2002). In all regions cooling around $3.48-3.47 \mathrm{Ma}$ is indicated by the development of open habitats. Till deposits in the James Bay lowland, Canada, provide evidence for glaciations between 3.6 and 3.4 Ma (Gao et al., 2012). A further opening of the vegetation and deterioration of climate is observed both in northern Norway and the north-eastern Russian Arctic after 3.35 Ma, culminating in the coldest recorded climatic conditions around 3.3 Ma. High Sphagnum spore content in ODP Hole 642B and the Lake El'gygytgyn record are indicative of an extensive distribution of peatlands during the coldest 


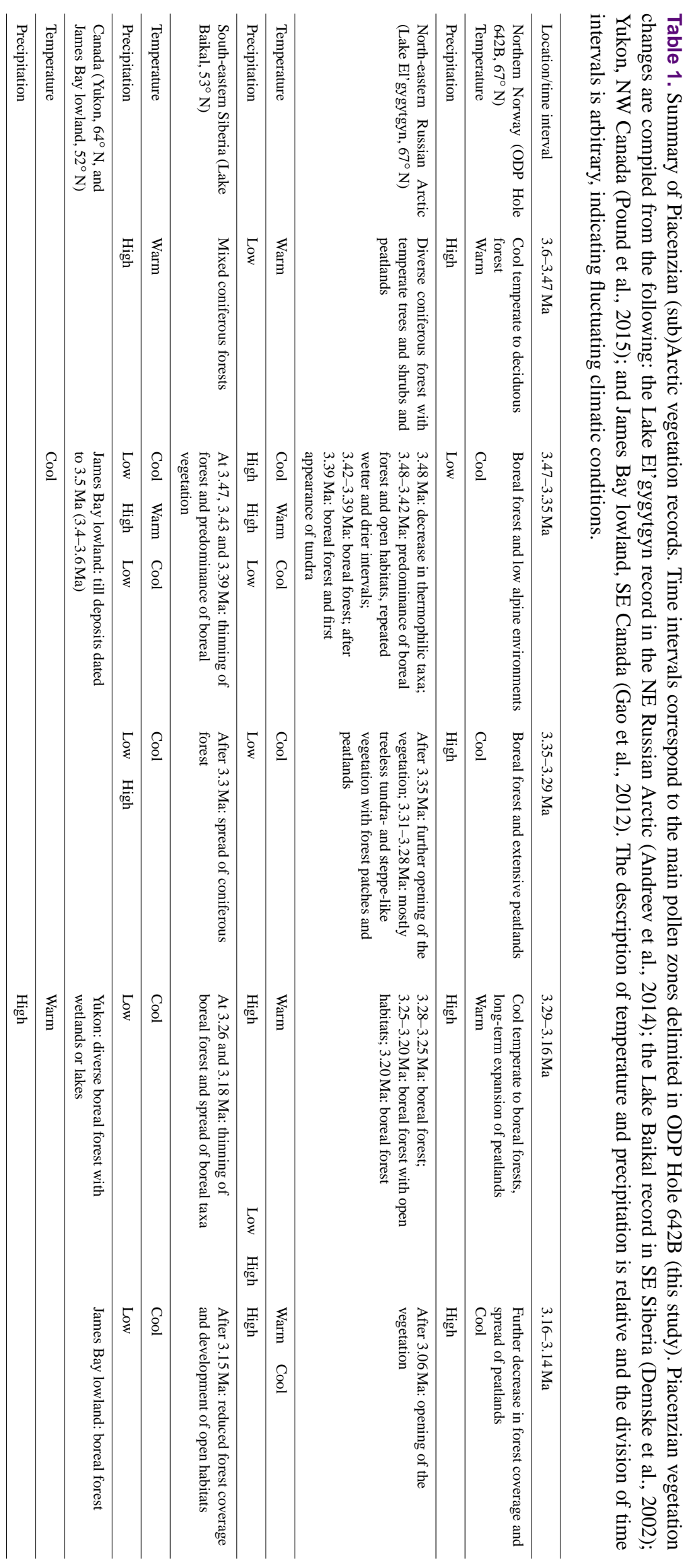


interval (Andreev et al., 2014). Warm climatic conditions reestablished themselves after ca. 3.29 Ma in northern Norway, the north-eastern Russian Arctic and southern east Siberian, which were interrupted by cooler intervals until ca. $3.18 \mathrm{Ma}$ (Andreev et al., 2014; Demske et al., 2002). However, conifer forests prevailed under relatively warm climatic conditions in the vicinity of Lake El'gygytgyn until 3.06 Ma. Piacenzian deposits from the Yukon territory, Canada, have been assigned to the MPWP and reveal the prevalence of diverse forests with wetlands or lakes (Pound et al., 2015). Between 3.18 and $3.14 \mathrm{Ma}$, reduced forest coverage in northern Norway and in the Lake Baikal area and the predominance of boreal forest in the James Bay lowland are indicative of cool climatic conditions (Demske et al., 2002; Gao et al., 2012).

\section{Conclusion}

The Piacenzian high-resolution pollen record from ODP Hole 642B in the Norwegian Sea reveals repeated fluctuation of cool temperate and boreal conditions. Warmestmonth temperatures are estimated to be $8-14{ }^{\circ} \mathrm{C}$ higher than at present. The northern boundary of the boreonemoral to nemoral forest zone was shifted northward by at least 4$8^{\circ}$ latitude during warmer-than-present intervals. Throughout the Piacenzian record (ca. 3.6-3.14 Ma), three main climatic phases are observed:

- 3.60-3.47 Ma: cool temperate deciduous to mixed forest prevailed in northern Norway, suggesting a northward shift of vegetation boundaries of at least $4-8^{\circ}$ latitude.

- 3.47-3.29 Ma: a southward shift of vegetation zones as well as a displacement of vegetation belts to lower altitudes indicates cooling. Low alpine environments develop in mountainous areas, suggesting climatic conditions similar to today. The cooling culminated at ca. 3.3 Ma (around MIS M2), potentially creating conditions cold enough for glacier build-up at the highest summits.

- 3.29-3.14 Ma: re-establishment of warmer-than-present climate conditions is indicated by remigration of deciduous to mixed forest to northern Norway. Repeated warmer and colder phases are recorded until ca. 3.18 Ma, after which climate continuously cools and conditions similar to MIS M2 establish themselves again. The development of peatlands might have contributed to the drawdown of atmospheric $\mathrm{CO}_{2}$ before the start of Northern Hemisphere glaciation.

Future studies will focus on comprehensive multi-proxy analyses of ODP Hole 642B. By combining data from terrestrial and marine palynomorphs with SST estimates based on alkenones and oxygen and carbonate isotopes these studies will further improve our understanding of the link between terrestrial and marine changes and the mechanisms causing Piacenzian climate changes in the Nordic Seas region.
Acknowledgements. We acknowledge the International Ocean Drilling Program for providing the samples. We thank M. Jones (Palynological Laboratory Services Ltd, North Wales) and L. Dunlop (Northumbria University) for help with sample preparation. We are grateful to A. Bjune (Uni Research Klima) for discussions on the modern vegetation of Norway. The work is part of the "Ocean Controls on high-latitude Climate sensitivity - a Pliocene case study" (OCCP) project, which is funded by the Norwegian Research Council (project 221712). Stijn De Schepper is grateful for funding from the Norwegian Research Council (project 229819). We would like to thank F. M. Sanchez Goñi, T. H. Donders and I. Baily for helpful comments that greatly improved the manuscript.

Edited by: A. Haywood

\section{References}

Andreassen, L. M., Winsvold, S. H., Paul, F., and Hausberg, J. E.: Inventory of Norwegian Glaciers, edited by: Andreassen, L. M. and Winsvold, S. H., Norwegian Water Resources and Energy Directorate, Oslo, 2012.

Andreev, A. A., Tarasov, P. E., Wennrich, V., Raschke, E., Herzschuh, U., Nowaczyk, N. R., Brigham-Grette, J., and Melles, M.: Late Pliocene and Early Pleistocene vegetation history of northeastern Russian Arctic inferred from the Lake El'gygytgyn pollen record, Clim. Past, 10, 1017-1039, doi:10.5194/cp-10-1017-2014, 2014.

Anell, I., Thybo, H., and Artemieva, I. M.: Cenozoic uplift and subsidence in the North Atlantic region: Geological evidence revisited, Tectonophysics, 474, 78-105, doi:10.1016/j.tecto.2009.04.006, 2009.

Badger, M. P. S., Schmidt, D. N., Mackensen, A., and Pancost, R. D.: High-resolution alkenone palaeobarometry indicates relatively stable $p \mathrm{CO}_{2}$ during the Pliocene (3.3-2.8 Ma), Philos. T. R. Soc. A, 371, 20130094, doi:10.1098/rsta.2013.0094, 2013.

Ballantyne, A. P., Rybczynski, N., Baker, P. A., Harington, C. R., and White, D.: Pliocene Arctic temperature constraints from the growth rings and isotopic composition of fossil larch, Palaeogeogr. Palaeocl., 242, 188-200, doi:10.1016/j.palaeo.2006.05.016, 2006.

Ballantyne, A. P., Greenwood, D. R., Sinninghe Damsté, J. S., Csank, A. Z., Eberle, J. J., and Rybczynski, N.: Significantly warmer Arctic surface temperatures during the Pliocene indicated by multiple independent proxies, Geology, 38, 603-606, doi:10.1130/G30815.1, 2010.

Bartoli, G., Hönisch, B., and Zeebe, R. E.: Atmospheric $\mathrm{CO}_{2}$ decline during the Pliocene intensification of Northern Hemisphere glaciations, Paleoceanography, 26, PA4213, doi:10.1029/2010PA002055, 2011.

Bennike, O., Abrahamsen, N., Bak, M., Israelson, C., Konradi, P., Matthiessen, J., and Witkowski, A.: A multi-proxy study of Pliocene sediments from Île de France, North-East Greenland, Palaeogeogr. Palaeocl., 186, 1-23, 2002.

Beug, H. J.: Leitfaden der Pollenbestimmung für Mitteleuropa und angrenzende Gebiete, Dr. Friedrich Pfeil, München, 2004.

Birks, H. J. B. and Line, J. M.: The use of rarefaction analysis for estimating palynological richness from Quaternary pollen-analytical data, Holocene, 2, 1-10, doi:10.1177/095968369200200101, 1992. 
Bjune, A., Birks, H. J. B., and Seppä, H.: Holocene vegetation and climate history on a continental-oceanic transect in northern Fennoscandia based on pollen and plant macrofossils, Boreas, 33, 211-223, doi:10.1080/03009480410001244, 2004.

Bjune, A. E.: Holocene vegetation history and tree-line changes on a north-south transect crossing major climate gradients in southern Norway-evidence from pollen and plant macrofossils in lake sediments, Rev. Palaeobot. Palyno., 133, 249-275, doi:10.1111/j.1502-3885.2004.tb01142.x, 2005.

Bjune, A. E. and Birks, H. J. B.: Holocene vegetation dynamics and inferred climate changes at Svanåvatnet, Mo i Rana, northern Norway, Boreas, 37, 146-156, doi:10.1111/j.15023885.2007.00006.x, 2008.

Bleil, U.: 40. Magnetostratigraphy of Neogene and Quaternary Sediment Series from the Norwegian Sea: Ocean Drilling Program, Leg 104, Proc. Ocean Drill. Program, Scientific Results, 104, 829-901, 1989.

Brigham-Grette, J., Melles, M., Minyuk, P., Andreev, A., Tarasov, P., DeConto, R., Koenig, S., Nowaczyk, N., Wennrich, V., Rosén, P., Haltia, E., Cook, T., Gebhardt, C., Meyer-Jacob, C., Snyder, J., and Herzschuh, U.: Pliocene Warmth, Polar Amplification, and Stepped Pleistocene Cooling Recorded in NE Arctic Russia, Science, 340, 1421-1427, doi:10.1126/science.1233137, 2013.

Costin, A. B., Gray, M., Totterdell, C. J., and Wimbush, D. J.: Kosciuszko Alpine Flora, CSIRO publishing, Melbourne, Australia, 2000.

Demske, D., Mohr, B., and Oberhänsli, H.: Late Pliocene vegetation and climate of the Lake Baikal region, southern East Siberia, reconstructed from palynological data, Palaeogeogr. Palaeocl., 184, 107-129, 2002.

Demske, D., Tarasov, P. E., and Nakagawa, T.: Atlas of pollen, spores and further non-pollen palynomorphs recorded in the glacial-interglacial late Quaternary sediments of Lake Suigetsu, central Japan, Quaternary. Int., 290-291, 164-238, doi:10.1016/j.quaint.2012.02.002, 2013.

De Schepper, S., Groeneveld, J., Naafs, B. D. A., Van Renterghem, C., Hennissen, J., Head, M. J., Louwye, S., and Fabian, K.: Northern Hemisphere Glaciation during the Globally Warm Early Late Pliocene, PLoS One, 8, e81508, doi:10.1371/journal.pone.0081508, 2013.

De Schepper, S., Gibbard, P. L., Salzmann, U., and Ehlers, J.: A global synthesis of the marine and terrestrial evidence for glaciation during the Pliocene Epoch, Earth-Sci. Rev., 135, 83-102, doi:10.1016/j.earscirev.2014.04.003, 2014.

de Vernal, A. and Mudie, P. J.: Pliocene and Pleistocene palynostratigraphy at ODP Sites 646 and 647, eastern and southern Labrador Sea, in: Proceedings of the Ocean Drilling Program, Scientific Results, 105, 401-422, Ocean Drilling Program College Station, Texas, 1989a.

de Vernal, A. and Mudie, P. J.: Late Pliocene to Holocene palynostratigraphy at ODP Site 645, Baffin Bay, in Proceedings of the Ocean Drilling Program, Scientific Results, 105, 387-399, 1989b.

Diekmann, M.: Deciduous forest vegetation in Boreo-nemoral Scandinavia, Acta Phytogeogr. Suec., 80, 1-112, 1994.

Dowsett, H., Robinson, M., Haywood, A. M., Salzmann, U., Hill, D., Sohl, L. E., Chandler, M., Williams, M., Foley, K., and Stoll, D. K.: The PRISM3D paleoenvironmental reconstruction, Stratigraphy, 7, 123-139, 2010.
Dowsett, H. J.: The PRISM palaeoclimate reconstruction and Pliocene sea-surface temperature, in: Deep-Time Perspectives on Climate Change: Marrying the Signal from Computer Models and Biological Proxies, edited by: Williams, M., Haywood, A. M., Gregory, F. J., and Schmidt, D. N., 459-480, 2007.

Dowsett, H. J., Foley, K. M., Stoll, D. K., Chandler, M. A., Sohl, L. E., Bentsen, M., Otto-Bliesner, B. L., Bragg, F. J., Chan, W.-L., Contoux, C., Dolan, A. M., Haywood, A. M., Jonas, J. A., Jost, A., Kamae, Y., Lohmann, G., Lunt, D. J., Nisancioglu, K. H., Abe-Ouchi, A., Ramstein, G., Riesselman, C. R., Robinson, M. M., Rosenbloom, N. A., Salzmann, U., Stepanek, C., Strother, S. L., Ueda, H., Yan, Q., and Zhang, Z.: Sea Surface Temperature of the mid-Piacenzian Ocean: A Data-Model Comparison, Sci. Rep., 3, 1-8, doi:10.1038/srep02013, 2013.

Eidvin, T., Riis, F., and Rasmussen, E. S.: Oligocene to Lower Pliocene deposits of the Norwegian continental shelf, Norwegian Sea, Svalbard, Denmark and their relation to the uplift of Fennoscandia: A synthesis, Mar. Petrol. Geol., 56, 184-221, doi:10.1016/j.marpetgeo.2014.04.006, 2014.

Erdtman, G., Berglund, B., and Praglowski, J.: An introduction to a Scandinavian pollen flora, Almqvist \& Wiksells, Uppsala, 1961.

Faegri, K. and Iversen, J.: Textbook of Pollen Analysis, Wiley \& Sons, Chichester, 1989.

Figueiral, I., Mosbrugger, V., Rowe, N. P., Ashraf, A. R., Utescher, T., and Jones, T. P.: The miocene peat-forming vegetation of northwestern Germany: An analysis of wood remains and comparison with previous palynological interpretations, Rev. Palaeobot. Palyno., 104, 239-266, doi:10.1016/S00346667(98)00059-1, 1999.

Fronval, T. and Jansen, E.: Late Neogene paleoclimates and paleoceanography in the Iceland-Norwegian Sea: evidence from the Iceland and Vøring Plateaus, Proc. Ocean Drill. Program, Scientific Results, 151, 455-468, 1996.

Gajewski, K., Viau, A., Sawada, M., Atkinson, D., and Wilson, S.: Sphagnum peatland distribution in North America and Eurasia during the past 21,000 years, Global Biogeochem. Cy., 15, 297310, doi:10.1029/2000GB001286, 2001.

Gallimore, R. G. and Kutzbach, J. E.: Role of orbitally induced changes in tundra area in the onset of glaciation, Nature, 381 , 503-505, doi:10.1038/381503a0, 1996.

Gao, C., McAndrews, J. H., Wang, X., Menzies, J., Turton, C. L., Wood, B. D., Pei, J., and Kodors, C.: Glaciation of North America in the James Bay Lowland, Canada, 3.5 Ma, Geology, 40, 975-978, 2012.

Gibbard, P. L., Head, M. J., and Walker, M. J. C.: Formal ratification of the Quaternary System/Period and the Pleistocene Series/Epoch with a base at 2.58 Ma, J. Quaternary Sci., 25, 96102, doi:10.1002/jqs.1338, 2010.

Grimm, E. C.: CONISS: a FORTRAN 77 program for stratigraphically constrained cluster analysis by the method of incremental sum of squares, Comput. Geosci., 13, 13-35, 1987.

Grimm, E. C.: TILIA and TILIA* GRAPH. PC spreadsheet and graphics software for pollen data, INQUA, Work. Gr. DataHandling Methods Newsl., 4, 5-7, 1990.

Hammer, Ø., Harper, D. A. T., and Ryan, P. D.: Paleontological statistics software package for education and data analysis, Palaeontol. Electron., 4, 9-18, doi:10.1016/j.bcp.2008.05.025, 2001. 
Hansen, B. and Østerhus, S.: North Atlantic-Nordic Seas exchanges, Prog. Oceanogr., 45, 109-208, doi:10.1016/S00796611(99)00052-X, 2000.

Haywood, A. M., Dolan, A. M., Pickering, S. J., Dowsett, H. J., McClymont, E. L., Prescott, C. L., Salzmann, U., Hill, D. J., Hunter, S. J., and Lunt, D. J.: On the identification of a Pliocene time slice for data-model comparison, Philos. T. R. Soc. A, 371, 121, 2013a.

Haywood, A. M., Hill, D. J., Dolan, A. M., Otto-Bliesner, B. L., Bragg, F., Chan, W.-L., Chandler, M. A., Contoux, C., Dowsett, H. J., Jost, A., Kamae, Y., Lohmann, G., Lunt, D. J., Abe-Ouchi, A., Pickering, S. J., Ramstein, G., Rosenbloom, N. A., Salzmann, U., Sohl, L., Stepanek, C., Ueda, H., Yan, Q., and Zhang, Z.: Large-scale features of Pliocene climate: results from the Pliocene Model Intercomparison Project, Clim. Past, 9, 191-209, doi:10.5194/cp-9-191-2013, 2013b.

Heusser, L. E.: Pollen distribution in the bottom sediments of the western North Atlantic ocean, Mar. Micropaleontol., 8, 77-88, 1983.

Hilgen, F. J., Lourens, L. J., and Van Dam, J. A.: Chapter 29 - The Neogene Period, in: The Geologic Time Scale, Elsevier, Burlington, MA, USA, 923-978, 2012.

Hill, D. J.: The non-analogue nature of Pliocene temperature gradients, Earth Planet. Sc. Lett., 425, 232-241, doi:10.1016/j.epsl.2015.05.044, 2015.

IPCC: Summary for Policymakers, in Climate Change 2013: The Physical Science Basis, Contribution of Working Group I to the Fifth Assessment Report of the Intergovemmental Panel on Climate Change, edited by: Stocker, T. F., Qin, D., Plattner, G.-K., Tignor, M., Allen, S. K., Boschung, J., Nauels, A., Xia, Y., Bex, V., and Midgley, P. M., Cambridge University Press, Cambridge, United Kingdom and New York, NY, USA, 2013.

Ishikawa, S. and Watanabe, N.: An ecological study on the Sciadopitys verticillata forest and other natural forests of Mt. Irazu, southern Shikoku, Japan, Mem.-Fac. Sci. Kochi Univ. Ser. D Biol., 7, 63-66, 1986.

Jansen, E. and Sjøholm, J.: Reconstruction of Glaciation over the Past 6 Myr from Ice-Borne Deposits in the Norwegian Sea, Lett. to Nat., 349, 600-603, 1991.

Khélifi, N., Sarnthein, M., and Naafs, B. D. A.: Technical note: Late Pliocene age control and composite depths at ODP Site 982, revisited, Clim. Past, 8, 79-87, doi:10.5194/cp-8-79-2012, 2012.

Kleiven, H., Jansen, E., Fronval, T., and Smith, T. M.: Intensification of Northern Hemisphere glaciations in the circum Atlantic region (3.5-2.4 Ma) - ice-rafted detritus evidence, Palaeogeogr. Palaeocl., 184, 213-223, 2002.

Knies, J., Mattingsdal, R., Fabian, K., Grøsfjeld, K., Baranwal, S., Husum, K., De Schepper, S., Vogt, C., Andersen, N., Matthiessen, J., Andreassen, K., Jokat, W., Nam, S.-I., and Gaina, C.: Effect of early Pliocene uplift on late Pliocene cooling in the Arctic-Atlantic gateway, Earth Planet. Sc. Lett., 387, 132-144, doi:10.1016/j.eps1.2013.11.007, 2014.

Koenig, S. J., DeConto, R. M., and Pollard, D.: Late Pliocene to Pleistocene sensitivity of the Greenland Ice Sheet in response to external forcing and internal feedbacks, Clim. Dynam., 37, 1247-1268, doi:10.1007/s00382-011-1050-0, 2011.

Lawrence, K. T., Herbert, T. D., Brown, C. M., Raymo, M. E., and Haywood, A. M.: High-amplitude variations in North Atlantic sea surface temperature during the early Pliocene warm period,
Paleoceanography, 24, PA2218, doi:10.1029/2008PA001669, 2009.

Lawrence, K. T., Bailey, I., and Raymo, M. E.: Re-evaluation of the age model for North Atlantic Ocean Site 982 - arguments for a return to the original chronology, Clim. Past, 9, 2391-2397, doi:10.5194/cp-9-2391-2013, 2013.

Lisiecki, L. E. and Raymo, M. E.: A Pliocene-Pleistocene stack of 57 globally distributed benthic $\delta^{18} \mathrm{O}$ records, Paleoceanography, 20, PA1003, doi:10.1029/2004PA001071, 2005.

Lunt, D. J., Foster, G. L., Haywood, A. M., and Stone, E. J.: Late Pliocene Greenland glaciation controlled by a decline in atmospheric $\mathrm{CO}_{2}$ levels, Nature, 454, 1102-1105, 2008.

Lunt, D. J., Haywood, A. M., Schmidt, G. A., Salzmann, U., Valdes, P. J., Dowsett, H. J., and Loptson, C. A.: On the causes of midPliocene warmth and polar amplification, Earth Planet. Sc. Lett., 321-322, 128-138, doi:10.1016/j.eps1.2011.12.042, 2012.

MacDonald, G. M., Beilman, D. W., Kremenetski, K. V., Sheng, Y., Smith, L. C., and Velichko, A. A.: Rapid Early Development of Circumarctic Peatlands and Atmospheric $\mathrm{CH}_{4}$ and $\mathrm{CO}_{2}$ Variations, Science, 314, 285-288, doi:10.1126/science.1131722, 2006.

Martínez-Botí, M. A., Foster, G. L., Chalk, T. B., Rohling, E. J., Sexton, P. F., Lunt, D. J., Pancost, R. D., Badger, M. P. S., and Schmidt, D. N.: Plio-Pleistocene climate sensitivity evaluated using high-resolution $\mathrm{CO}_{2}$ records, Nature, 518, 49-54, doi:10.1038/nature14145, 2015.

Miller, G. H., Alley, R. B., Brigham-Grette, J., Fitzpatrick, J. J., Polyak, L., Serreze, M. C., and White, J. W. C.: Arctic amplification: can the past constrain the future?, Quaternary Sci. Rev., 29, 1779-1790, doi:10.1016/j.quascirev.2010.02.008, 2010.

Moe, D.: Identification Key for Trilete Microspores of Fennoscandian Pteridophyta, Grana, 14, 132-142, 1974.

Moen, A.: The regional vegetation of Norway; that of central Norway in particular, Nord. Geogr. Tidsskr., 41, 179-226, 1987.

Moen, A.: National Atlas of Norway: vegetation, Norwegian Mapping Authority, Hønefoss, Norway, 1999.

Mork, M.: Circulation phenomena and frontal dynamics of the Norwegian coastal current, Philos. T. R. Soc. Lond., 302, 635-647, 1981.

Mosbrugger, V. and Utescher, T.: The coexistence approach - a method for quantitative reconstructions of Tertiary terrestrial palaeoclimate data using plant fossils, Palaeogeogr. Palaeocl., 134, 61-86, 1997.

Mudie, P. J.: Pollen distribution in recent marine sediments, eastern Canada, Can. J. Earth Sci., 19, 729-747, 1982.

Mudie, P. J. and McCarthy, F. M. G.: Late Quaternary pollen transport processes, western North Atlantic: Data from box models, cross-margin and N-S transects, Mar. Geol., 118, 79-105, 1994.

Mudie, P. J. and McCarthy, F. M. G.: Marine palynology: potentials for onshore-offshore correlation of Pleistocene-Holocene records, T. Roy. Soc. S. Afr., 61, 139-157, 2006.

Naafs, B. D. A., Stein, R., Hefter, J., Khélifi, N., De Schepper, S., and Haug, G. H.: Late Pliocene changes in the North Atlantic Current, Earth Planet. Sc. Lett., 298, 434-442, doi:10.1016/j.eps1.2010.08.023, 2010.

Nilsen, J. E. Ø. and Nilsen, F.: The Atlantic Water flow along the Vøring Plateau: Detecting frontal structures in oceanic station time series, Deep-Sea Res. Pt. I, 54, 297-319, doi:10.1016/j.dsr.2006.12.012, 2007. 
Norwegian Meteorological Institute and Norwegian Broadcasting Corporation: YR, available at: http://www.yr.no/ (last access: 1 March 2015), 2014.

Numata, M.: The flora and vegetation of Japan, Tokyo etc., Kodansha x, Illus. maps Geog., 2, 294 pp., 1974.

Orvik, K. A.: Major pathways of Atlantic water in the northern North Atlantic and Nordic Seas toward Arctic, Geophys. Res. Lett., 29, 2-1-2-4, doi:10.1029/2002GL015002, 2002.

Pagani, M., Liu, Z., LaRiviere, J., and Ravelo, A. C.: High Earthsystem climate sensitivity determined from Pliocene carbon dioxide concentrations, Nat. Geosci., 3, 27-30, 2010.

Pound, M. J., Tindall, J., Pickering, S. J., Haywood, A. M., Dowsett, H. J., and Salzmann, U.: Late Pliocene lakes and soils: a global data set for the analysis of climate feedbacks in a warmer world, Clim. Past, 10, 167-180, doi:10.5194/cp-10-167-2014, 2014.

Pound, M. J., Lowther, R. I., Peakall, J., Chapman, R. J., and Salzmann, U.: Palynological evidence for a warmer boreal climate in the Late Pliocene of the Yukon Territory, Canada, Palynology, 39, 91-102, doi:10.1080/01916122.2014.940471, 2015.

Risebrobakken, B., Andersson, C., De Schepper, S., and McClymont, E.: Pliocene climate phases and transitions in the eastern Nordic Seas, Paleoceanography, in review, 2016.

Robinson, M. M.: New quantitative evidence of extreme warmth in the Pliocene Arctic, Stratigraphy, 6, 265-275, 2009.

Romero-Wetzel, M. B.: Struktur und Bioturbation des Makrobenthos auf dem Vöring-Plateau (Norwegische See), Berichte Sonderforschungsbereich 313, Universität Kiel, Kiel, 13, 1-204, 1989.

Rybczynski, N., Gosse, J. C., Harington, C. R., Wogelius, R. A., Hidy, A. J., and Buckley, M.: Mid-Pliocene warm-period deposits in the High Arctic yield insight into camel evolution., Nat. Commun., 4, 1550, doi:10.1038/ncomms2516, 2013.

Salzmann, U., Haywood, A. M., Lunt, D. J., Valdes, P. J., and Hill, D. J.: A new global biome reconstruction and data-model comparison for the middle Pliocene, Global Ecol. Biogeogr., 17, 432447, 2008.

Salzmann, U., Haywood, A. M., and Lunt, D. J.: The past is a guide to the future? Comparing Middle Pliocene vegetation with predicted biome distributions for the twenty-first century, Philos. T. R. Soc. A, 367, 189-204, 2009.

Salzmann, U., Dolan, A. M., Haywood, A. M., Chan, W.-L., Voss, J., Hill, D. J., Abe-Ouchi, A., Otto-Bliesner, B., Bragg, F. J., Chandler, M. A., Contoux, C., Dowsett, H. J., Jost, A., Kamae, Y., Lohmann, G., Lunt, D. J., Pickering, S. J., Pound, M. J., Ramstein, G., Rosenbloom, N. A., Sohl, L., Stepanek, C., Ueda, $\mathrm{H}$., and Zhang, Z.: Challenges in quantifying Pliocene terrestrial warming revealed by data-model discord, Nature Climate Change, 3, 969-974, 2013.

Schneider, W.: Palaeohistological studies on Miocene brown coals of Central Europe, Int. J. Coal Geol., 28, 229-248, doi:10.1016/0166-5162(95)00019-4, 1995.
Seki, O., Foster, G. L., Schmidt, D. N., Mackensen, A., Kawamura, K., and Pancost, R. D.: Alkenone and boron-based Pliocene $p \mathrm{CO}_{2}$ records, Earth Planet. Sc. Lett., 292, 201-211, 2010.

Seppä, H. and Birks, H. J. B.: July mean temperature and annual precipitation trends during the Holocene in the Fennoscandian tree-line area: pollen-based climate reconstructions, The Holocene, 11, 527-539, doi:10.1191/095968301680223486, 2001.

Shipboard Scientific Party: 4. Site 642: Norwegian Sea, edited by: Eldholm, O., Thiede, J., and Taylor, E., Init. Repts., 104, Ocean Drilling Program, College Station, TX, 53-453, 1987.

Sohl, L. E., Chandler, M. A., Schmunk, R. B., Mankoff, K., Jonas, J. A., Foley, K. M., and Dowsett, H. J.: PRISM3/GISS Topographic Reconstruction, US Geol. Surv. Data Ser., 419, 6 pp., 2009.

Stockmarr, J.: Tablets with spores used in absolute pollen analysis, Pollen et spores, 13, 615-621, 1971.

Svenning, J. C.: Deterministic Plio-Pleistocene extinctions in the European cool-temperate tree flora, Ecol. Lett., 6, 646-653, doi:10.1046/j.1461-0248.2003.00477.x, 2003.

Thompson, R. S. and Fleming, R. F.: Middle Pliocene vegetation: Reconstructions, paleoclimatic inferences, and boundary conditions for climate modeling, Mar. Micropaleontol., 27, 27-49, doi:10.1016/0377-8398(95)00051-8, 1996.

Utescher, T. and Mosbrugger, V.: The Palaeoflora Database, available at: http://www.palaeoflora.de (last access: 21 September 2015), 2013.

Wen, J.: Evolution of Eastern Asian and Eastern North American Disjunct Distributions in Flowering Plants, Annu. Rev. Ecol. Syst., 30, 421-455, doi:10.1146/annurev.ecolsys.30.1.421, 1999.

Willard, D. A.: Palynological record from the North Atlantic region at $3 \mathrm{Ma}$ : vegetational distribution during a period of global warmth, Rev. Palaeobot. Palyno., 83, 275-297, doi:10.1016/0034-6667(94)90141-4, 1994.

Willard, D. A.: Pliocene-Pleistocene pollen assemblages from the Yermak Plateau, Arctic Ocean: Sites 910 and 911, Proc. Ocean Drill. Program, Scientific Results, 151, 297-305, 1996.

Xing, Y., Gandolfo, M. A., and Linder, H. P.: The Cenozoic biogeographical evolution of woody angiosperms inferred from fossil distributions, Global Ecol. Biogeogr., 1290-1301, doi:10.1111/geb.12383, 2015.

Zhang, Z.-S., Nisancioglu, K. H., Chandler, M. A., Haywood, A. M., Otto-Bliesner, B. L., Ramstein, G., Stepanek, C., Abe-Ouchi, A., Chan, W.-L., Bragg, F. J., Contoux, C., Dolan, A. M., Hill, D. J., Jost, A., Kamae, Y., Lohmann, G., Lunt, D. J., Rosenbloom, N. A., Sohl, L. E., and Ueda, H.: Mid-pliocene Atlantic Meridional Overturning Circulation not unlike modern, Clim. Past, 9, 1495-1504, doi:10.5194/cp-9-1495-2013, 2013. 